\title{
Why far right parties do well at times of crisis: the role of labour market institutions
}

Tim Vlandas and Daphne Halikiopoulou

Working Paper 2016.07 


\section{Why far right parties do well at times of crisis: the role of labour market institutions}

Tim Vlandas and Daphne Halikiopoulou

Working Paper 2016.07

european trade union institute 
Tim Vlandas is Lecturer in Politics and Daphne Halikiopoulou is Associate Professor in Comparative Politics, University of Reading. Contact: t.vlandas@reading.ac.uk

\author{
Brussels, 2016 \\ ๑Publisher: ETUI aisbl, Brussels \\ All rights reserved \\ Print: ETUI Printshop, Brussels \\ D/2016/10.574/30 \\ ISSN: $1994-4446$ (print version) \\ ISSN: 1994-4454 (electronic version)
}

The ETUI is financially supported by the European Union. The European Union is not responsible for any use made of the information contained in this publication. 


\section{Contents}

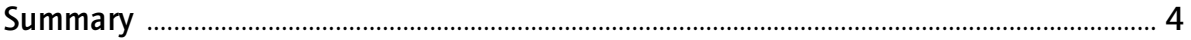

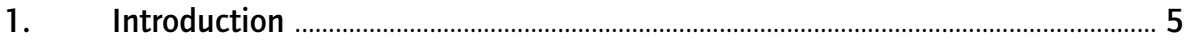

2. The extreme and radical variants of the far right and EP elections …….......... 7

3. The economic determinants of far right party support …………………........... 11

$3.1 \quad$ Theoretical expectations .................................................................................................... 11

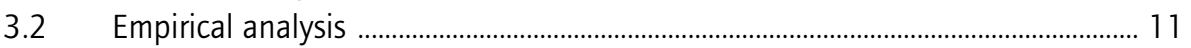

4. Bringing labour market institutions back into the debate on right-wing extremism ................................................................................................. 16

4.1 What matters is not the economy per se but the mediating effect of specific policies ........................................................................................................... 16

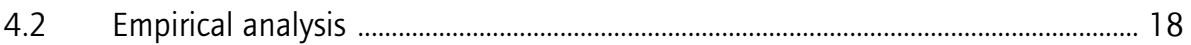

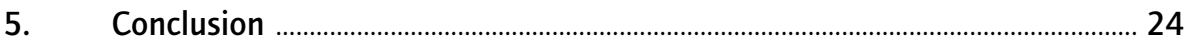

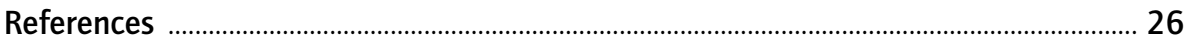

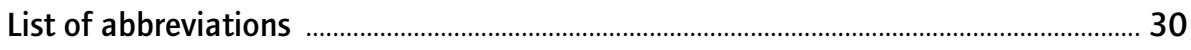

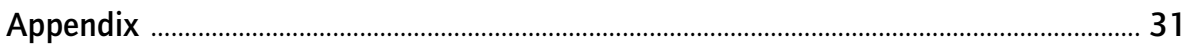




\section{Summary}

The far right is on the rise in many western and eastern European countries. The 2008 Eurozone crisis is an obvious source of blame for this phenomenon; indeed, a large body of literature suggests that economic malaise prompts support for far right parties. This conventional wisdom, however, is not consistent with cross-national patterns of unemployment and far right votes in the last three European Parliament (EP) elections. To solve this puzzle, we argue that it is specific labour market policies rather than the economic crisis itself that are more likely to facilitate the rise of the far right. In many countries over the past three decades, governments have deregulated employment protection legislation (EPL) and reduced unemployment benefits; but it was precisely these labour market institutions that offered protection from the insecurity and deprivation that economic malaise imposes on societies. We test our hypothesis on the last three EP elections and find that unemployment and GDP growth have not played a role in far right support, while labour market institutions have had an impact that is both direct and indirect, by limiting the effect of unemployment. Studying unemployment benefits also revealed a similar phenomenon of direct and indirect correlation: where unemployment benefits are generous, unemployment has no association with the far right, but where they are not, unemployment correlates with higher far right support. Employment protection legislation has only an indirect association that is conditional on unemployment benefits. Where unemployment benefits are low, EPL mediates the impact of unemployment, but where unemployment benefits are generous, there is no mediating impact of EPL. This suggests that the policies of austerity are likely to intensify support for the far right in EP elections, therefore undermining the European integration project itself. 


\section{Introduction}

Since the onset of the 2008 Eurozone crisis, the far right has made significant gains across Europe. Given the conventional wisdom on the link between economic malaise and support for the far right, many see this political development as a clear and direct consequence of the economic crisis. As unemployment rises, growth stalls and wages stagnate or fall - so the argument goes - many voters become dissatisfied with the mainstream and turn to the far right.

The results of the recent 2014 European Parliament elections, which saw tremendous gains for the far right, are often regarded as confirmation of this argument. But while appealing, this conventional wisdom is not consistent with the patterns of far right support and unemployment that have developed since 2000. As Figure 1 shows, there is no clear positive relationship between the unemployment rate prior to an election and the share of votes that far right parties get. Thus, for instance, while Spain has the second highest rate of unemployment among the EU-28, it did not experience a rise in far right party support, with both Spain 2000 and National Democracy (DN) remaining marginalised. In Portugal too, the National Renovator Party (PNR) experienced no rise in its electoral performance despite the country's economic malaise. Other countries meanwhile, such as the UK and Denmark, did experience a rise in far right party support despite having lower unemployment rates.

This is because, we argue, it is not the crisis itself that facilitates the rise of the far right but rather the policy context prior to its development and the crisis policy responses that were consequently adopted by governments across Europe. ${ }^{1}$ More specifically, labour market institutions have been weakened in the last two decades and, by pursuing austerity, governments have worsened the situation. This is problematic because it is precisely these institutions that were meant to protect broad swaths of the population from the vagaries of the market, including economic crises. In particular, employment protection legislation (EPL), which had already been deregulated in many European countries prior to the crisis, was reduced even further. This has resulted in higher levels of insecurity among the employed. The economic impact on those who lose their job has also been intensified by the simultaneous cuts made to unemployment benefits prior to the crisis.

This working paper unfolds as follows: we first examine the differences between the radical and extreme variants of the far right and discuss the literature

1. See Halikiopoulou and Vlandas (2015) for a thorough test of this argument. 
on the determinants of far right support. We use the last three EP elections to test these determinants and show that there is little evidence to support many of the factors highlighted by this literature. Next, we show how the welfare state literature gives rise to the expectation that labour market institutions play a key role in mitigating the impact of unemployment on insecurity. Results from regression analyses of the last three EP elections suggest that unemployment benefits directly reduce - and limit the impact of unemployment on - far right support. While EPL does not have a direct effect on far right support, it does mediate the extent to which unemployment has an effect on far right voting patterns; however, this mediating effect can only be identified where unemployment benefit schemes are not generous. The last section concludes.

Figure 1 Unemployment rate and far right support in both western and eastern Europe in the last three EP elections

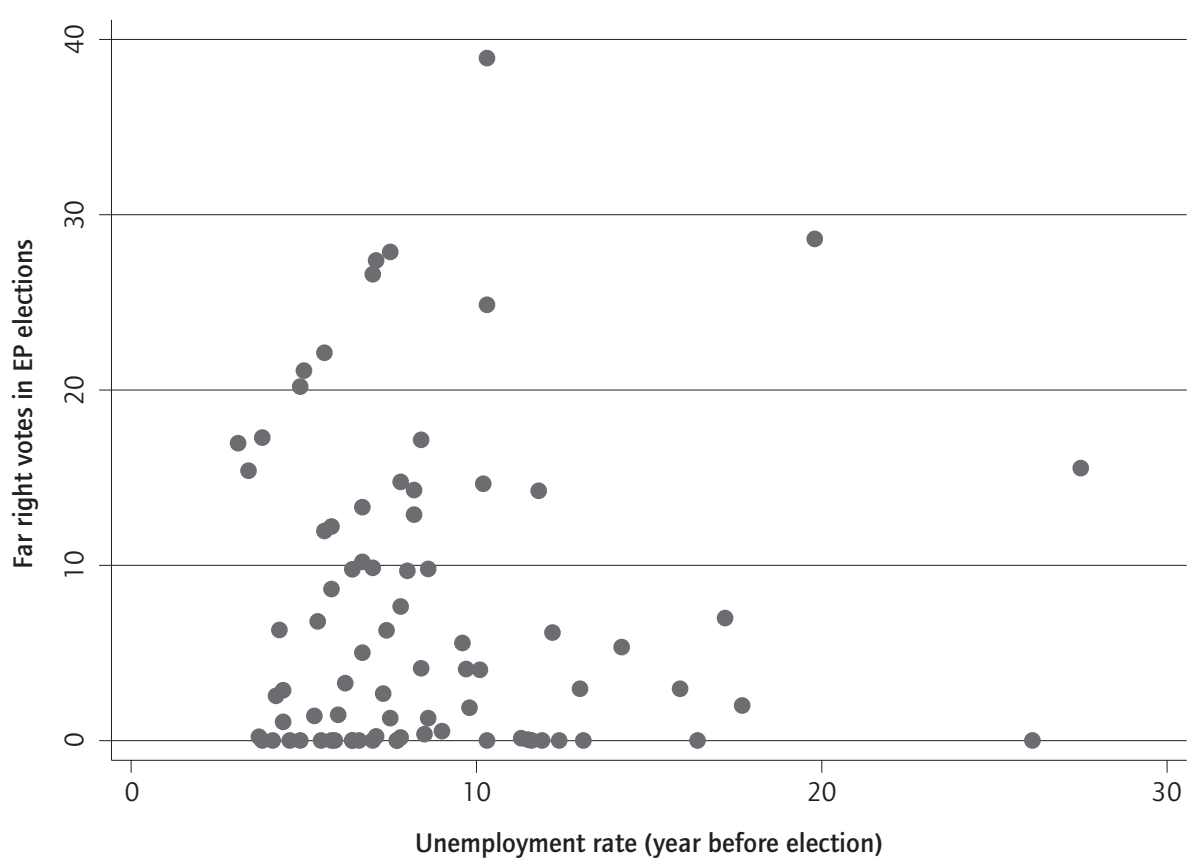

Note: each point represents the far right vote and unemployment rate for a given country in an election. 


\section{The extreme and radical variants of the far right and EP elections}

In this paper we adopt the umbrella term 'far right' to denote political parties on the fringes of the system that share an anti-immigrant agenda premised on nationalism, i.e. the need to protect the nation and its identity from outsiders. We distinguish between extreme and radical variants. This distinction captures differences within the far right party family relating to their relationship with fascism and democracy, as well as the extent to which these parties pursue their agendas through the adoption of violence. Extreme variants reject democracy altogether and tend to emphasise fascist and/or Nazi ideals in their manifestos. They often adopt violence. Radical variants, on the other hand, accept procedural democracy, reject the fascist label and put forward an agenda that emphasises ideological as opposed to a racial opposition to immigration. These parties justify exclusion not on the basis of ethnic or racial background but on the basis of ideological intolerance and incompatibility with 'our' democracy (Halikiopoulou et al 2013).

Using the term 'far right' allows us to capture both the similarities and differences within this party family. On the one hand, grouping political parties into 'party families' is a common way of classifying them (Mair and Mudde 1998) for the purposes of operationalization and comparison. Parties that belong to the same party family are assumed to be comparable groups, and a comparison of parties within a party family and/or between party families is assumed to wield generalizable conclusions. On the other hand, precisely because of the heterogeneity of this party family, we need to be careful in accounting for differences in terms of voting base, association with fascism, opposition to the EU, the degree to which these parties accept procedural and substantive democracy and the use of explicit racism in their manifestos. The presence of 'borderline' cases also poses difficulties by often blurring the distinction between far right parties and those on the fringes of the mainstream. By using the term 'far right', we cover a range of parties that we categorise as comparable but not necessarily identical in terms of their ideology, their origins and their organisational structures. We use this term to designate all parties that claim ownership of the immigration issue, which they justify on the basis of nationalism (Eatwell 2000; Hainsworth 2008; Halikiopoulou et al. 2012), despite differing from each other in terms of their relationship with democracy, the extent to which they have a fascist past and the extent to which violence forms part of their agenda (Halikiopoulou and Vlandas 2015). These criteria inform their classification within the 'extreme' and 'radical' sub-categories. Overall we identify 36 'far right' parties in $28 \mathrm{EU}$ member states (see Appendix 1) and have coded their national electoral results in European Parliament (EP) elections. 
EP elections are second-order 'national contests' (Hix and Marsh 2007). They are fought in the shadow of first-order contests and are used to influence the result of the next national election. For this reason, EP elections tend to give citizens an opportunity to vote for parties that are closer to their ideal preferences. Voters treat EP elections as mid-term contests in the battle to win national government office and they use them primarily to punish governing parties (Hix and Marsh 2007).

As such, EP election results provide a good platform for testing the impact of the economy on far right party support at the national level across Europe. They offer a 'snapshot' of $\mathbf{2 8}$ different elections with results at a particular point in time, using a comparatively similar electoral rule. EP elections also provide a good reference point for understanding the rise of both radical right variants, which have been the most popular types of far right parties since the 1990s, and the more extreme variants that have experienced a rise in support more recently, such as the Hungarian Jobbik and the Greek Golden Dawn. Finally, EP elections provide a platform on which to test a model of far right party support across both western and eastern Europe, which are rarely examined together.

The last three EP elections have seen an overall rising trend of far right parties across Europe; Figures 2 and 3 show the evolution of the far right in western and eastern Europe respectively. This phenomenon is neither necessarily linear nor generalizable across the EU. For example, in countries such as Spain, Portugal and Cyprus, support for the far right has been consistently low. In France, the Front National (FN) experienced a decline in support in 2009 but made a significant recovery in 2014. In Bulgaria and Italy, far right support declined in 2014. However, in many cases the trend has been an upward one, with a significant rise in countries such as Greece, Denmark, Sweden, Finland and the UK. 
Figure 2 Far right votes in the last three EP elections in western Europe

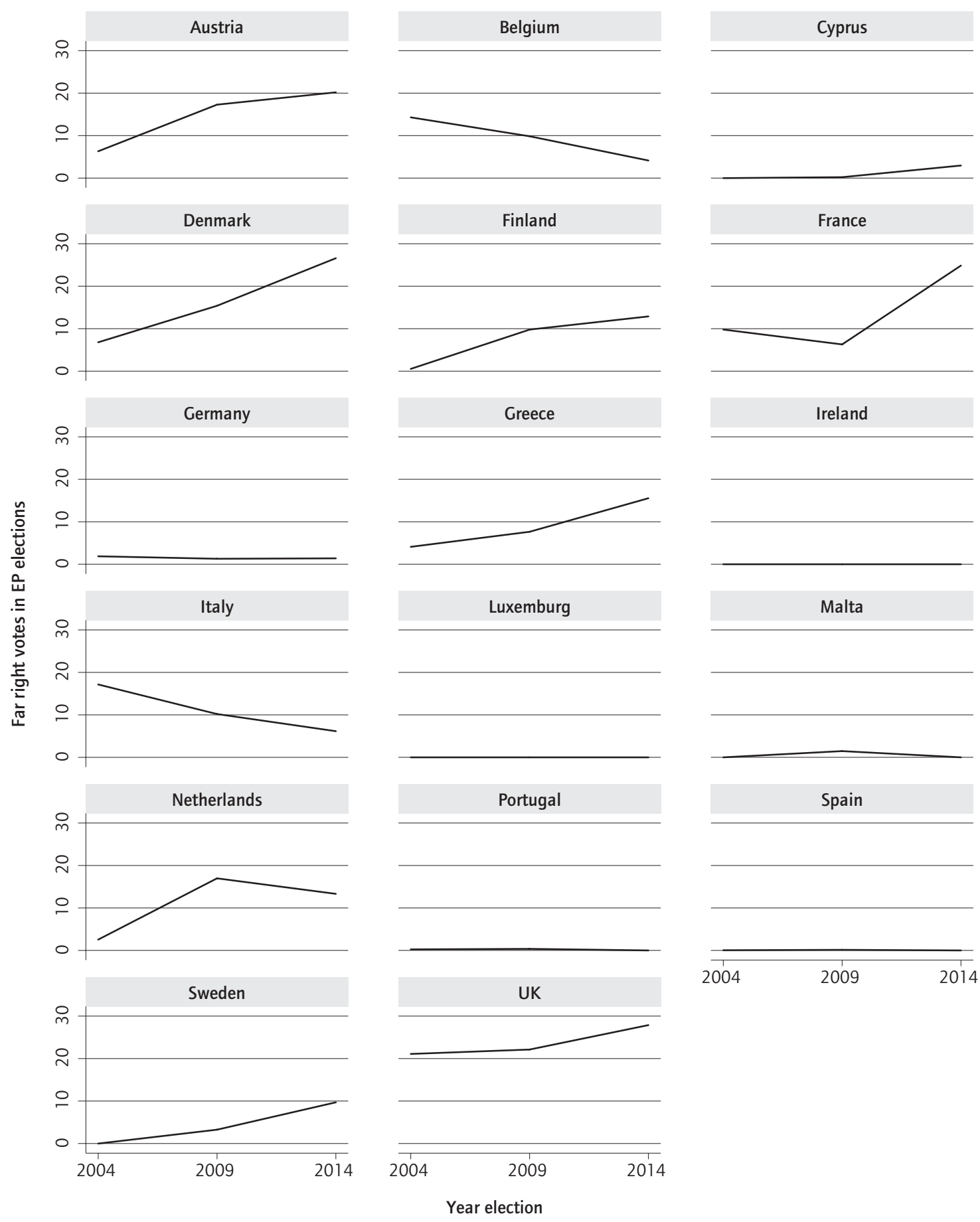


Figure 3 Far right votes in the last three EP elections in eastern Europe
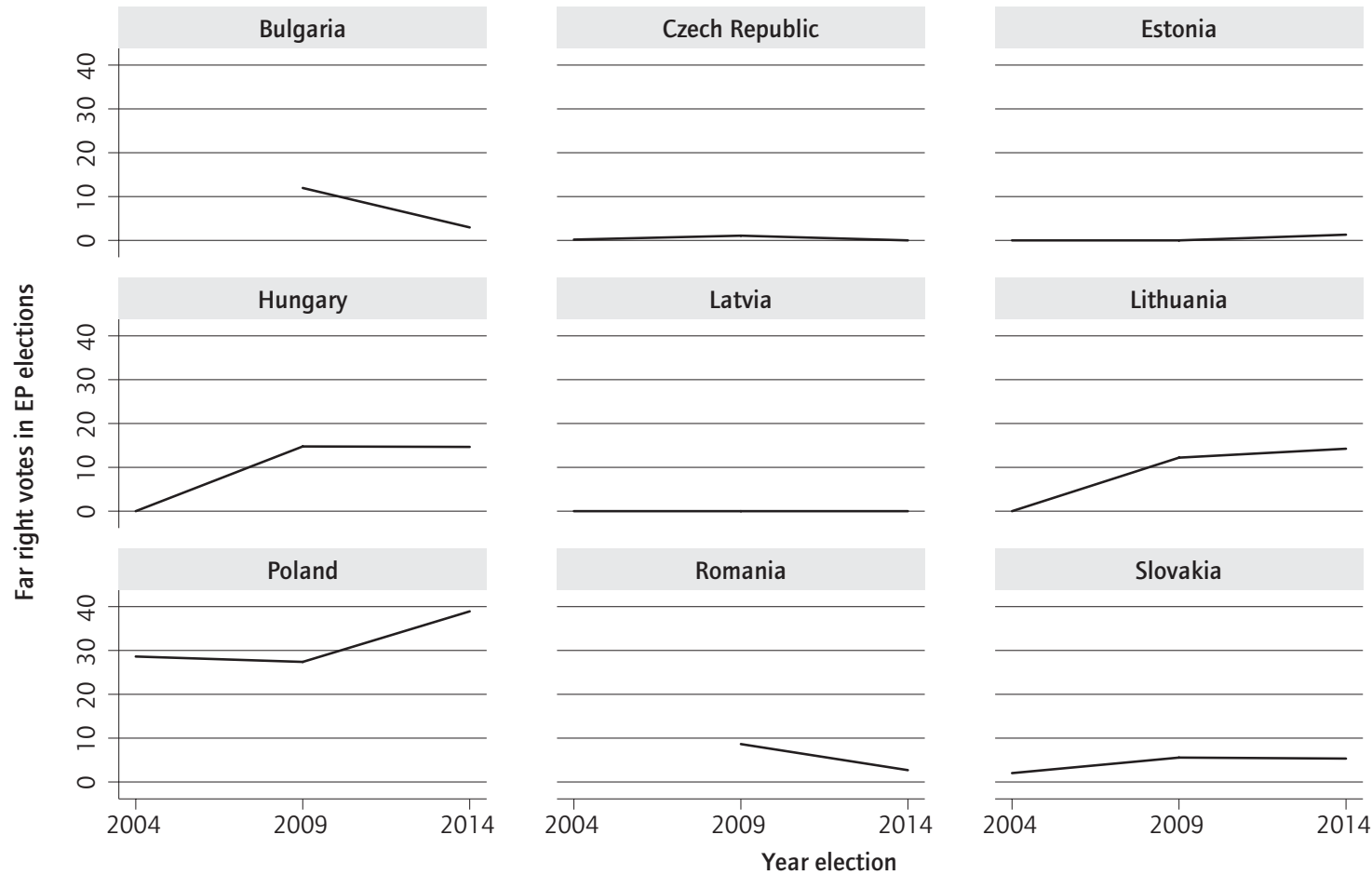


\section{The economic determinants of far right party support}

\subsection{Theoretical expectations}

How can we understand the rise of the far right in Europe? A large body of literature focuses on the link between far right party support and economic distress. The premise is that economic crises tend to create societies of winners and losers, thus facilitating conditions favourable to right-wing extremism (Mudde 2010). Far right parties are the most prominent beneficiaries of financial crises because they capitalise on the heightened economic uncertainty through a blame-shifting rhetoric that excludes outsiders from the nation; at times when resources appear to be scarce, these parties seek to restrict access to the collective goods of the state (see for example Golder 2003; Cochrane and Nevitte 2014). Scholars point out that the rise of the far right has historically coincided with economic crisis, a principal example being the rise of fascism and Nazism during the interwar period (Lipset 1960).

Empirically, however, this does not seem to apply as a general rule. First of all, the findings are conflicted: different conclusions drawn in various studies, both within and across cases, have prompted scholars to note that demand-side economic factors in themselves may be poor predictors of far right party support (Mudde 2010; Lucassen and Lubbers 2012) and that cultural factors may be more important. Lucassen and Lubbers (2012), for example, argue that perceived 'cultural ethnic' threats appear to be a stronger predictor of far right preferences than perceived 'economic ethnic' threats. Second, far right party support does not directly correlate with unemployment; there is no strong correlation suggested between cross-national variation in the unemployment rate and far right party support. However, a bivariate correlation alone does not present a sufficient test of the link between unemployment and far right support. In the next section we devise a more systematic empirical test using time series cross-section regression analysis.

\subsection{Empirical analysis}

We have collected data on several national-level variables that allow us to test the determinants of far right support that have been identified in previous literature (as discussed above). Where data is available, all independent variables are for the year before the election takes place. This is because all elections take place in May, which means it makes more sense to test, for example, the effect of unemployment for the year before rather than for the current year. In some cases, data is not available for 2013 and we therefore 
have to rely on 2012 data (or in a very few cases on 2011 data) but this is never the case for fast-moving economic variables. Descriptive statistics, definitions and sources of all variables are discussed in Table A2 in the appendix.

We rely on the overall unemployment rate (as \% of total) firstly because it captures the biggest problem in the labour market, but also because it receives the most attention from the public. However, we also test whether using the change instead of the level of unemployment yields different results. We include a number of controls for demand-side factors, the first set of controls being real GDP growth. We also test for the effect of budgetary stress (debt and deficit as \% of GDP). A second control concerns the impact of deindustrialisation, which has received some attention in the literature on far right politics (e.g. Kitschelt 2007). The third set of controls concerns the role of internationalisation, which previous literature has also focused on. Kriesi (2014), for example, argues that the populist right is more likely to mobilise in defence of the nation-state and national identity, concepts that internationalisation may undermine. Following Lucassen and Lubbers' (2012) argument about perceived 'cultural ethnic threats', any international forces that threaten the state (e.g. globalisation) or national identity (e.g. immigration) could be expected to correspond with higher far right support. We include two measures to test these expectations: first, we include total trade (sum of exports and imports) as a share of GDP and second, we investigate whether immigration affects far right support.

To account for supply-side dynamics, we consider the role of several factors. First, to gain an idea of the extent to which national electoral systems allow for the representation of far right votes in national elections, we rely on whether there is a proportional representation (PR) electoral system in the country. We expect PR systems to exhibit lower far right support in EP elections because dissatisfied voters can voice their discontent in national elections. Second, we consider the extent to which the party system is open by including an index of electoral fractionalisation. ${ }^{2}$ Finally, considering the variations between eastern and western Europe (Mudde 2007; Halikiopoulou et al 2012), we capture whether countries have a communist past by including a dummy variable: coded 1 where the condition is present and o where it is not.

As our focus is on EP elections, it is important to control for EU-level dynamics. First, participation in the European elections varies enormously by country. It is therefore important to control for voter turnout in the EP elections as a percentage of the total of eligible voters. Second, literature on Euroscepticism shows that attitudes towards European integration affect voting preferences in EP elections (Hix and Marsh 2007). We therefore control for the percentage of people who answered 'a good thing' to the question: 'Generally speaking, do you think that (OUR COUNTRY)'s membership of the EU is...?'

2. Index of legislative fractionalisation of the party system according to the formula [F] proposed by Rae (1968). 
Our regressions report robust standard errors clustered by country, since autocorrelation and heteroscedasticity are likely to be present. Because we are interested in explaining variation across countries, the inclusion of country fixed effects would 'explain away' what we are trying to demonstrate. Indeed, as Plümper, Troeger and Manow (2005: 331) argue, 'unit dummies completely absorb differences in the level of independent variables across units'. Thus the 'level effect' of our key independent variables (e.g. unemployment benefits) is therefore suppressed when including country fixed effects (ibid: 333). Another problem with including fixed effects is that it would further reduce the degrees of freedom: including country dummies removes about half of the degrees of freedom from the model, thereby inflating standard errors. ${ }^{3}$

Figure 4 shows the results for our baseline model. Note that all independent variables are standardised around mean 0 with standard deviation of 1 which means the coefficients are directly comparable: they show the effect on far right support of a 1 standard deviation change in the independent variable. ${ }^{4}$ The unemployment rate has no statistically significant effect in all models, further corroborating the absence of correlation discussed earlier. Real GDP growth

Figure 4 Results from regression analysis of far right party support in the last three EP elections

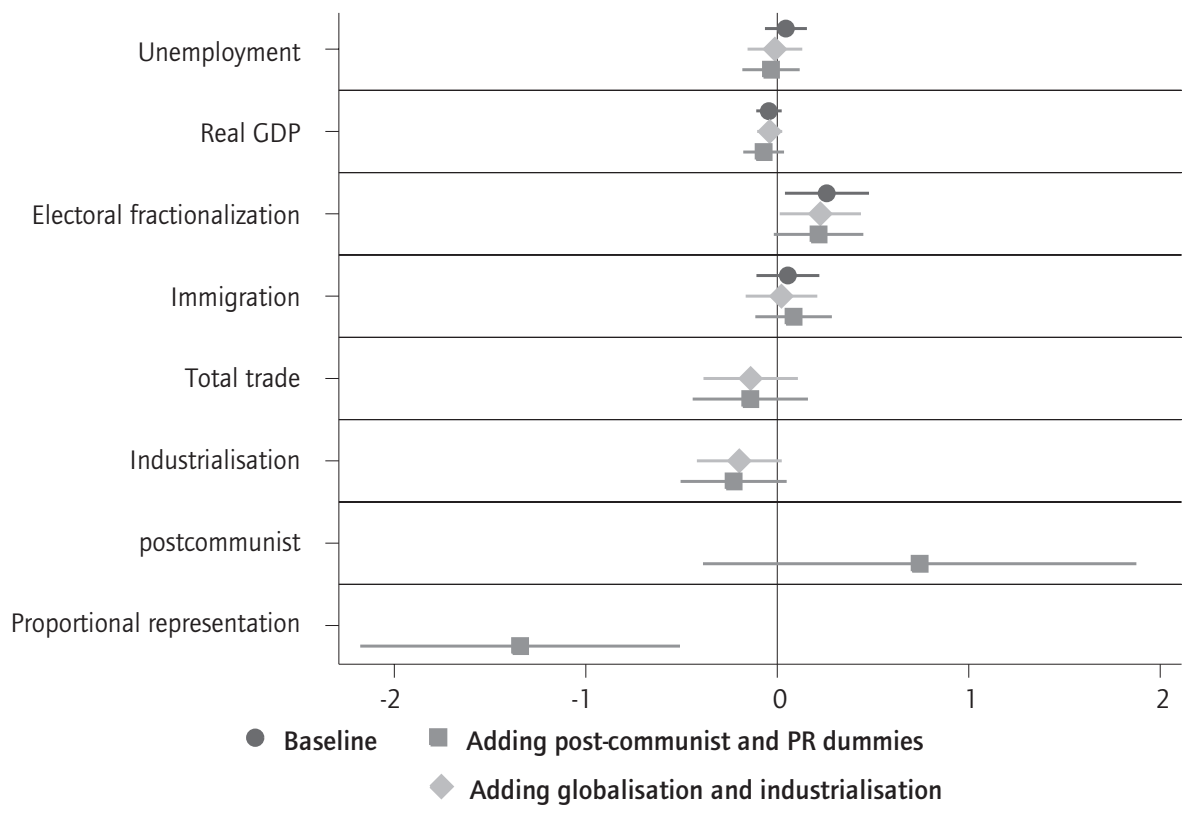

Note: $90 \%$ confidence interval. Both dependent and independent variables have been standardised with mean 0 and standard deviation of 1 . Thus, plotted coefficients show the effect of 1 standard deviation change in the independent variable on the dependent variable (except for the proportional representation dummy and postcommunist dummy that take values 0 or 1). Constant not shown. Full results can be found in Table A4 in the appendix.

3. We thank an anonymous reviewer for making this point.

4. Full results can be found in Table $\mathrm{A}_{4}$ in the appendix. 
and total trade are similarly statistically insignificant. The only two variables that are statistically significant are electoral fractionalisation, which increases far right support (only in baseline specification), and the proportional representation dummy which has a negative association with far right support. However, electoral fractionalisation is only statistically significant in the first models. In Figure 5 we rerun the same regression but substitute levels in unemployment with change in unemployment. The results are the same. Next, we introduce controls for EP voter turnout and support for Europe, which are not significant; only the proportional representation dummy is statistically significant (see Figure 6).

Figure 5 Results from regression analysis of far right party support in the last three EP elections, replacing 'level' with 'change' in unemployment

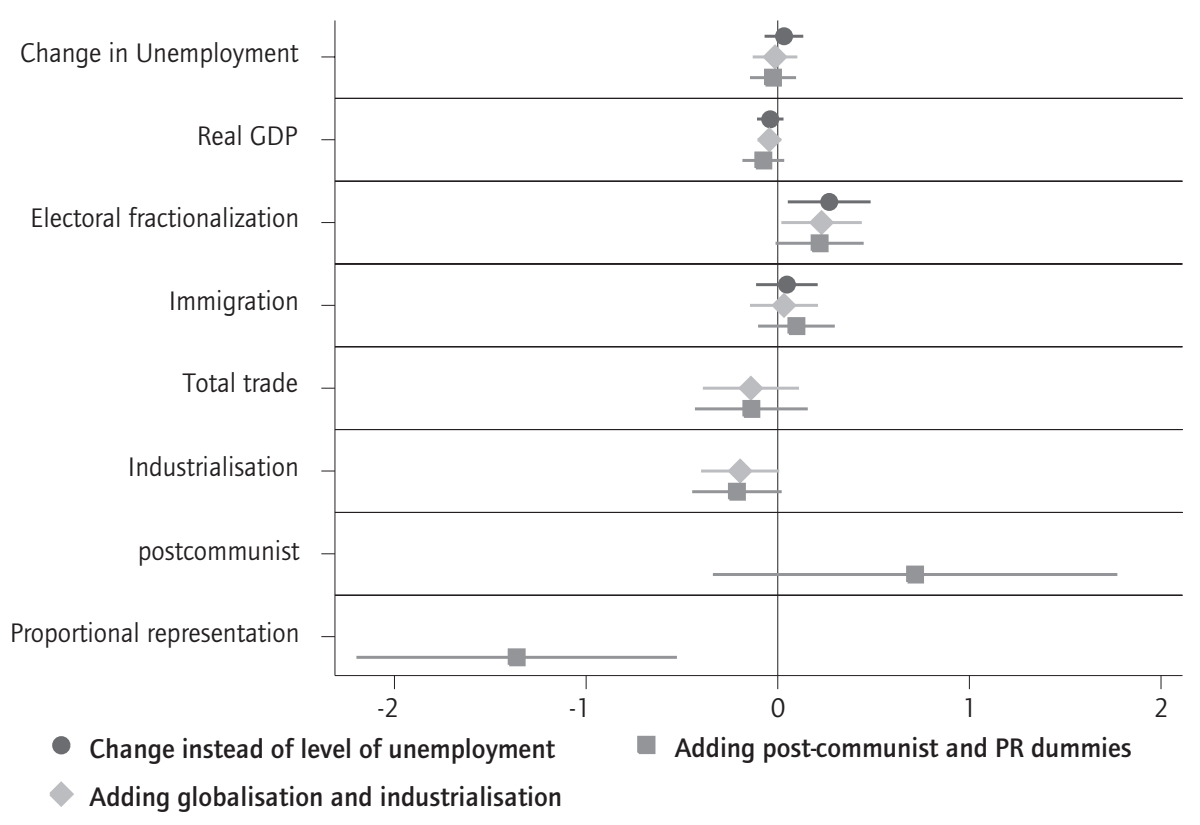

Note: $90 \%$ confidence interval. Both dependent and independent variables have been standardised with mean 0 and standard deviation of 1 . Thus, plotted coefficients show the effect of 1 standard deviation change in the independent variable on the dependent variable (except for the proportional representation dummy and postcommunist dummy that take values 0 or 1). Constant not shown. Full results can be found in Table A4 in the appendix. 
Figure 6 Results from regression analysis of far right party support in the last three EP elections, adding controls for EU level dynamics

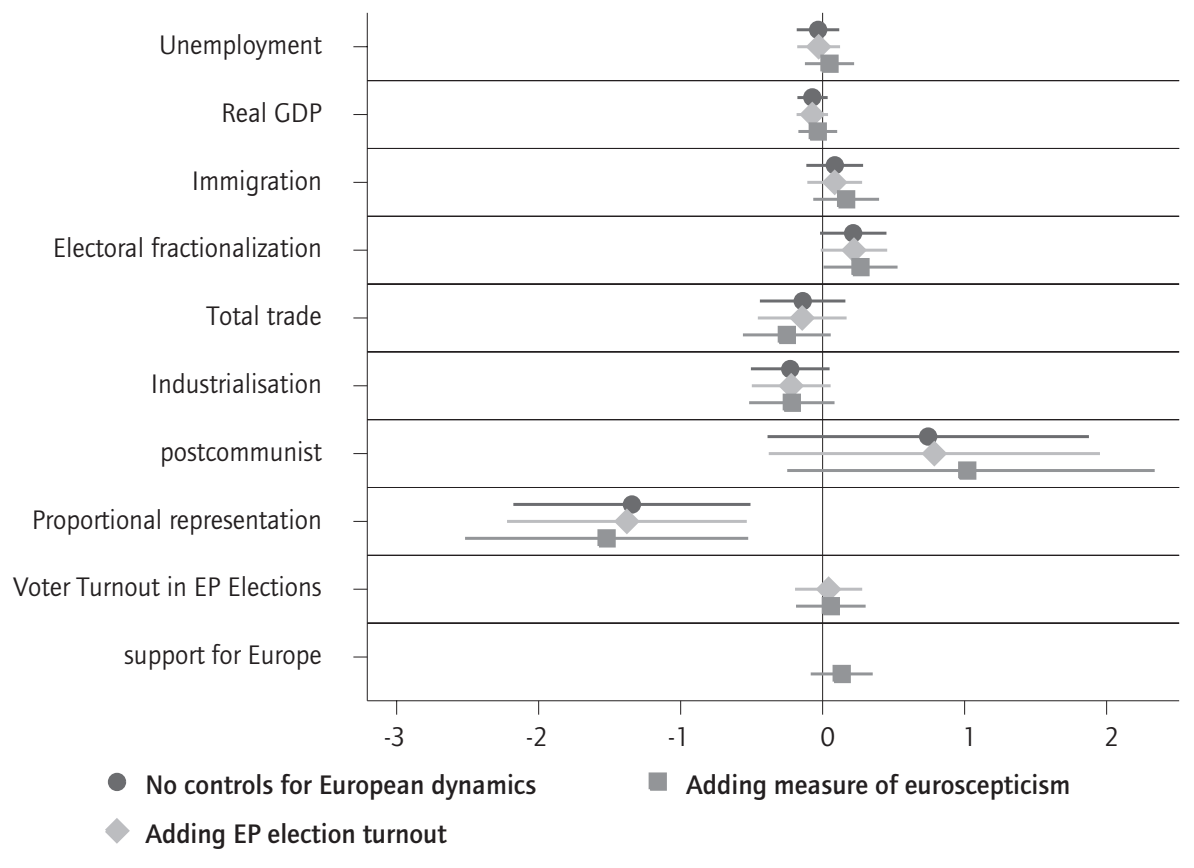

Note: $90 \%$ confidence interval. Both dependent and independent variables have been standardised with mean 0 and standard deviation of 1 . Thus, plotted coefficients show the effect of 1 standard deviation change in the independent variable on the dependent variable (except for the proportional representation dummy and postcommunist dummy that take values 0 or 1). Constant not shown. Full results can be found in Table A4 in the appendix. 


\section{Bringing labour market institutions back into the debate on right-wing extremism}

\subsection{What matters is not the economy per se but the mediating effect of specific policies}

So far we have shown that economic distress in itself is not significant; but what if we test more specifically the effect of the risks and costs of unemployment? We argue that the relationship between economic distress and far right party support is in fact a complex one and conditional on labour market institutions. In this section we test the extent to which policies that mediate the effect of unemployment have an impact on far right party support. We start by distinguishing the effect of unemployment on two different groups in the labour market: 'outsiders' (those who are unemployed or have precarious employment contracts) and 'insiders' (those who have permanent full-time contracts) (Emmenegger et al. 2012). Unemployment affects both the outsiders and the insiders (cf. Rueda, 2007). This is because while unemployment imposes a cost on those that are unemployed and no longer have an income, it also increases the subjective and objective insecurity of employed workers who may become more fearful of losing their job. In other words, unemployment may increase insecurity and hence lead to higher levels of far right support through two conceptually distinct channels: because it imposes costs on the unemployed and because it increases the risks for those that are employed. This distinction between employed insiders and unemployed outsiders is politically and economically salient because the last decades have been characterised by an increased labour market dualisation in which the risks, entitlements and policy preferences of these two groups diverged (Emmenegger et al. 2012).

Unemployment has been found to impact on various dimensions of welfare, such as well-being, life satisfaction, or other metrics (e.g. Jahoda 1988; Gerlach and Stephan 1996). In addition, workers that were previously unemployed continue to feel insecure even after returning to work (Böckerman 2004; Erlinghagen 2008). This in turn will affect their political preferences. For instance, previous literature has shown that those without a job or in precarious employment have differing policy preferences from those who currently have a permanent job (Rueda 2005; Rueda 2007; Emmenegger 2012; Vlandas 2013; Marx and Picot 2013; Marx 2014).

The effect of unemployment on outsiders and insiders is crucially mediated by labour market institutions. Clearly, workers who become unemployed suffer a loss of income; but the size of that loss depends on labour market institutions because in most European countries the unemployed are eligible to receive unemployment benefits that replace some of their previous income (Van Vliet 
and Caminada 2012). As a result, the cost of being unemployed depends on the generosity of the unemployment benefit scheme: in countries with generous benefits, the cost of unemployment relative to employment is lower than in countries where unemployment benefit replacement rates are low. In a recent analysis using the European Social Survey, Chung and van Oorschot (2011) confirm that generous unemployment benefits provide a sense of security by partly replacing lost income. 5

Table 1 shows that unemployment benefits have become less generous in many countries. ${ }^{6}$ Among the countries that have cut unemployment benefits between 2003 and 2009 the reductions range from $-0.02 \%$ in Germany to $-27.1 \%$ in Poland, $-31.0 \%$ in Latvia and $-36.4 \%$ in Romania. Others have increased the generosity of their benefits in this period. Note that since many countries have retrenched their benefits since 2009 and have at the same time experienced massive increases in far right party support (e.g. Greece), using 2009 as a proxy for 2013 if anything 'stacks the cards' against our argument.

Unemployment and labour market institutions also influence insiders' fear of being dismissed. Outsiders are only one labour market group that is adversely affected by rising unemployment; insiders in permanent employment may also be negatively affected when assessing the resulting higher risk that they will become unemployed and hence suffer a loss of income. While the real or perceived risk is most obviously determined by unemployment, it is also influenced by employment protection legislation (EPL): where EPL is high, dismissal regulations are stringent and an employer is (all other things being equal) less willing to dismiss an employee when economic activity falls, because the cost of firing the employee is higher. Consistent with this expectation, workers with permanent contracts that are protected by EPL exhibit different degrees of insecurity and different policy preferences from those with temporary contracts that are not protected (Clark and Postel Vinay 2005; Rueda 2007; Vlandas 2013).

Consequently, our expectation is that where EPL is high, permanent workers fear unemployment less because they are unlikely to be made redundant. This is confirmed by Mau, Mewes and Schöneck (2012: 17), who find a 'significant interaction between the unemployment rate and the employment protection index ... indicating that unemployment may indeed go along with higher insecurity, but only under conditions of relatively weak labour market regulation.' Where it is easier to dismiss them, permanent workers will therefore respond more fearfully to a rise in unemployment (for more on the effect of EPL on permanent workers, see Rueda 2005 and 2007; Emmenegger et al 2012; Vlandas 2013).

5. Note that this also seems to occur with welfare state spending in general: 'those living in countries with higher levels of welfare state spending are considerably less concerned about their future socio-economic standing than individuals living in countries with lower welfare state effort' (Mau, Mewes and Schöneck 2012: 17).

6. Unfortunately the latest data available for this dataset is 2009, which we therefore use as our last data point for unemployment benefits. 
While we expect high levels of unemployment to only correspond with higher levels of far right party support in countries with low EPL, our expectations concerning the direct effect of EPL itself on far right party support is more uncertain. This is because the literature on labour economics shows that EPL not only reduces flows into unemployment but also decreases the likelihood of finding a job for the unemployed (OECD 1994; Bassanini and Duval 2006, 2009). In principle, therefore, it is not clear which of the two effects dominate, and the two may well cancel each other out. Indeed, the evidence concerning the impact of EPL on unemployment is mixed (eg Baccaro and Rei 2007). The average effect of EPL is therefore uncertain: if the effect on workers dominates, unemployment should have a negative effect on far right support; if the effect on the unemployed dominates, the reverse should be true; and if both effects are equivalent, the association should be statistically insignificant.

As shown in Table 2, many governments in Europe have deregulated EPL in the last two decades. Between 2003 and 2013, almost all countries for which there is data deregulated EPL for regular workers, including Greece, the Czech Republic, Hungary, Portugal, Slovakia and Spain. However, a few countries, such as Germany and Ireland, in fact strengthened their EPL. In 2013, the top five countries with the highest index were Portugal, the Netherlands, Latvia, Slovenia and Germany. The UK and Ireland were among the countries with the lowest EPL indices.

\subsection{Empirical analysis}

We test the impact of labour market institutions that may mediate the effect of unemployment on far right support. We rely on the index of EPL for regular workers developed by the OECD. The higher the EPL index, the less likely workers on permanent contracts will fear losing their job in the face of increasing unemployment. To capture cost, we rely on the unemployment benefit replacement rate, which captures the size of income loss upon becoming unemployed.

The results are shown in Figure 7. The coefficient for unemployment benefits is statistically significant and negative, suggesting that more generous unemployment benefits are associated with lower far right support, while the coefficient for EPL is not statistically significant. Unemployment remains nonsignificant but immigration is now positive (in some specifications that do not control for EU-level dynamics) and significant while electoral fractionalisation has no effect. The coefficient for real GDP growth is negative and significant but is not stable across specifications. Similarly, the coefficient for industrialisation is negative and significant only in one specification.

In Table A5 (appendix), we exclude certain outliers and rerun the results. First, we exclude Poland (column 2), which is an outlier in terms of the level of far right support, and find that the results are unchanged. Second, we exclude Spain, which is an outlier in terms of unemployment, and again find that the results are unchanged (column 3). Third, we exclude all countries where far 
Table 1 Net unemployment replacement rate for an average worker in 2003, 2008 and 2009

\begin{tabular}{|c|c|c|c|c|c|}
\hline & \multirow[t]{2}{*}{2003} & \multirow[t]{2}{*}{2008} & \multirow[t]{2}{*}{2009} & \multicolumn{2}{|c|}{ Percentage change between 2003 and 2009} \\
\hline & & & & Negative changes & Positive changes \\
\hline Austria & 0.65 & 0.64 & 0.63 & $-3.0 \%$ & \\
\hline Belgium & 0.57 & 0.56 & 0.56 & $-1.2 \%$ & \\
\hline Bulgaria & 0.64 & 0.52 & 0.56 & $-12.5 \%$ & \\
\hline Cyprus & 0.74 & & & n.a. & \\
\hline Czech Republic & 0.50 & 0.50 & 0.52 & & $4.5 \%$ \\
\hline Denmark & 0.65 & 0.63 & 0.64 & $-2.3 \%$ & \\
\hline Estonia & 0.50 & 0.49 & 0.51 & & $0.8 \%$ \\
\hline Finland & 0.65 & 0.60 & 0.60 & $-8.6 \%$ & \\
\hline France & 0.70 & 0.70 & 0.70 & & $0.3 \%$ \\
\hline Germany & 0.71 & 0.71 & 0.71 & $-0.020 \%$ & \\
\hline Greece & 0.36 & 0.42 & 0.42 & & $18.0 \%$ \\
\hline Hungary & 0.44 & 0.43 & 0.42 & $-5.1 \%$ & \\
\hline Ireland & 0.47 & 0.55 & 0.59 & & $24.1 \%$ \\
\hline Italy & 0.61 & 0.73 & 0.73 & & $19.2 \%$ \\
\hline Lithuania & 0.42 & 0.49 & 0.49 & & $17.3 \%$ \\
\hline Latvia & 0.69 & 0.48 & 0.48 & $-31.0 \%$ & \\
\hline Luxembourg & 0.88 & 0.90 & 0.89 & & $1.2 \%$ \\
\hline Malta & 0.43 & 0.43 & 0.42 & $-3.0 \%$ & \\
\hline Netherlands & 0.75 & 0.72 & 0.71 & $-5.5 \%$ & \\
\hline Poland & 0.35 & 0.26 & 0.26 & $-27.1 \%$ & \\
\hline Portugal & 0.77 & 0.76 & 0.75 & $-2.2 \%$ & \\
\hline Romania & 0.79 & 0.48 & 0.50 & $-36.4 \%$ & \\
\hline Spain & 0.69 & 0.68 & 0.68 & $-1.3 \%$ & \\
\hline Slovak Republic & 0.55 & 0.58 & 0.57 & & $3.8 \%$ \\
\hline Slovenia & 0.68 & 0.64 & 0.64 & $-5.5 \%$ & \\
\hline Sweden & 0.67 & 0.55 & 0.53 & $-21.9 \%$ & \\
\hline United Kingdom & 0.46 & 0.39 & 0.41 & $-11.6 \%$ & \\
\hline
\end{tabular}

Note: Net unemployment replacement rate for an average worker, one earner couple with two children. Source: Olaf Van Vliet \& Koen Caminada (2012), 'Unemployment replacement rates dataset among 34 welfare states 1971-2009: An update, extension and modification of Scruggs' Welfare State Entitlements Data Set', NEUJOBS Special Report No. 2, Leiden University. Note that the years 2003, 2008 and 2009 are used for EP elections in 2004, 2009 and 2014, respectively. We use the year preceding the EP elections but are constrained by the latest data point available which is for 2009, and which we therefore use as a proxy for 2013. Data for the year 1995 is provided to give a sense of the long-term evolution of generosity.

right support is o because these countries might be characterised by the absence of far right parties (column 4). We find that the coefficient for electoral fractionalisation is positive and significant, as in some previous specifications. However, there are some noteworthy differences. First, the effects of immigration and being a post-communist country are now positive and significant, while the effect of industrialisation is negative and significant. The coefficient for proportional representation is no longer statistically significant.

In Figures 8 and 9, we run the same regression but this time we allow for interaction effects between unemployment, EPL and unemployment benefits. We find no support for a mediating impact of EPL. As expected, unemployment benefits mediate the impact of unemployment on the far right: in countries 
Table 2 OECD index of employment protection legislation for regular workers

\begin{tabular}{|l|r|r|r|r|}
\hline Country & \multicolumn{1}{|c|}{$\mathbf{2 0 0 3}$} & $\mathbf{2 0 0 8}$ & \multicolumn{1}{|c|}{$\mathbf{2 0 1 3}$} & Percentage change between 2008 and 2013 \\
\hline Austria & 2.62075 & 2.62075 & 2.62075 & $0.0 \%$ \\
\hline Belgium & 2.7568 & 2.7568 & 2.7568 & $0.0 \%$ \\
\hline Czech Republic & 2.96825 & 2.78685 & 2.69615 & $-9.2 \%$ \\
\hline Denmark & 2.56066 & 2.34637 & 2.39172 & $-6.6 \%$ \\
\hline Estonia & n.a. & 2.45862 & 2.11395 & n.a. \\
\hline Finland & 2.08333 & 2.0119 & 2.0119 & $-3.4 \%$ \\
\hline France & 2.72732 & 2.72732 & 2.6678 & $-2.2 \%$ \\
\hline Germany & 2.94898 & 3.08503 & 3.08503 & $4.6 \%$ \\
\hline Greece & 2.92971 & 2.92971 & 2.44218 & $-16.6 \%$ \\
\hline Hungary & 2.39569 & 2.39569 & 2.1695 & $-9.4 \%$ \\
\hline Ireland & 1.81179 & 1.90703 & 1.99773 & $10.3 \%$ \\
\hline Italy & 3.15136 & 3.15136 & 2.86565 & $-9.1 \%$ \\
\hline Latvia & n.a. & n.a. & 2.99036 & n.a. \\
\hline Luxemburg & n.a. & 2.71145 & 2.71145 & n.a. \\
\hline Netherlands & 2.9178 & 2.9178 & 2.92602 & $0.3 \%$ \\
\hline Poland & 2.55726 & 2.4144 & 2.4144 & $-5.6 \%$ \\
\hline Portugal & 4.09524 & 3.69048 & 2.81037 & $-31.4 \%$ \\
\hline Slovakia & 2.78968 & 2.65873 & 2.27948 & $-18.3 \%$ \\
\hline Slovenia & n.a. & 2.85771 & 2.8237 & n.a. \\
\hline Spain & 2.7551 & 2.7551 & 2.35544 & $-14.5 \%$ \\
\hline Sweden & 2.57653 & 2.57653 & 2.57653 & $0.0 \%$ \\
\hline UK & 1.67744 & 1.67744 & 1.55839 & $-7.1 \%$ \\
\hline
\end{tabular}

Note: The OECD indicators of employment protection legislation measure the procedures and costs involved in dismissing individuals or groups of workers.

where the unemployment benefit system is not generous, higher unemployment is associated with higher far right support; but where unemployment benefits are generous, there is no statistically significant association between unemployment and far right support. In Figure 10, we show the results of a model that also includes an interaction term between unemployment benefits with the change (rather than the level) of unemployment and find a similar mediating effect. Of note is that more than $10 \%$ of observations have unemployment benefit replacement rates of 0.4 or less (see histogram in appendix). As shown in Table 1, only five EU countries have unemployment benefit replacement rates inferior to 0.4 .

Finally, we wish to investigate whether the mediating effect of EPL is itself contingent on unemployment benefit systems. This is shown in Figure 11, which reveals that EPL only mediates the impact of unemployment on far right support in cases where benefits are not generous. For instance, where the unemployment benefit replacement rate is $30 \%$, unemployment is associated with higher support only when EPL is lower than 2.5 (more than $20 \%$ of observations have an EPL of 2 or less). The combination of EPL below 2.5 and unemployment benefit of $30 \%$ or less seems to be based only on one country (Poland) and the extent to which this finding can be generalised may therefore be limited. 
Figure 7 Results from regression analysis of far right party support in the last three EP elections, adding labour market institutions

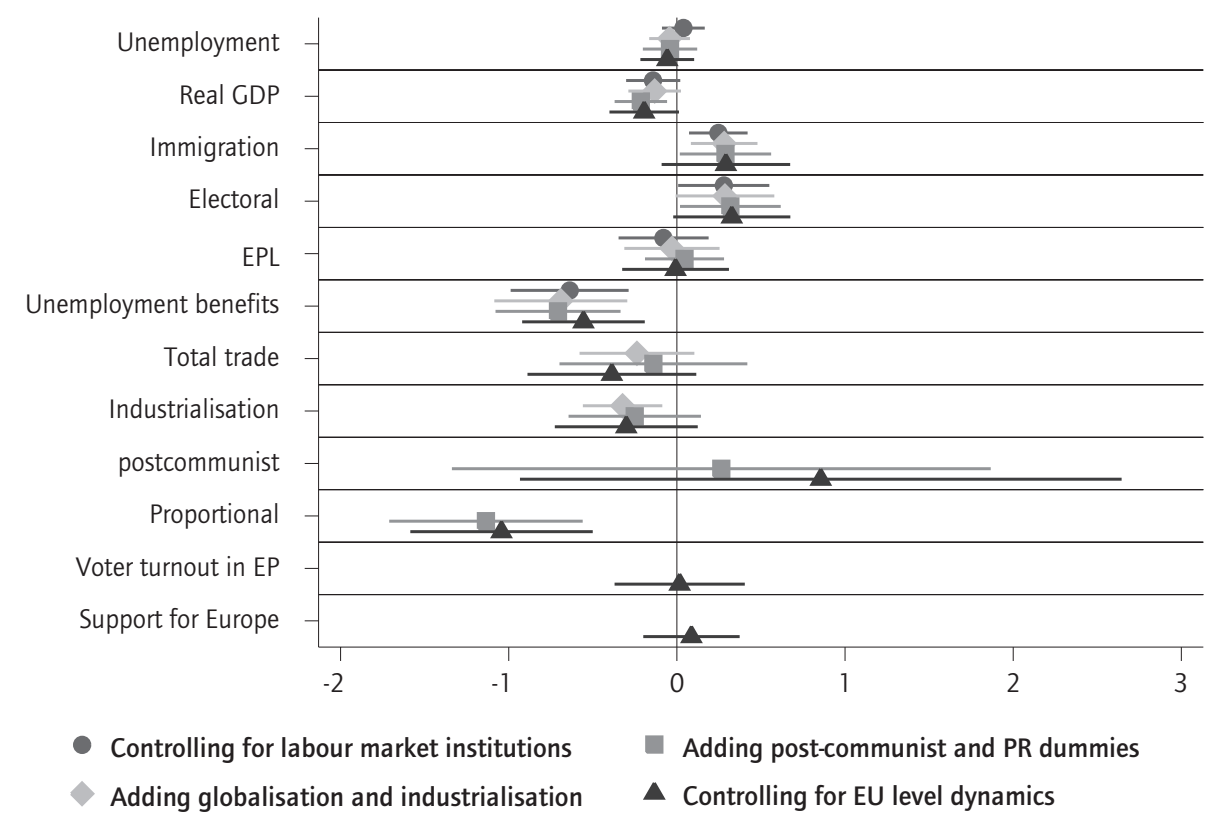

Note: $90 \%$ confidence interval. Both dependent and independent variables have been standardised with mean 0 and standard deviation of 1. Thus plotted coefficients show the effect of 1 standard deviation change in the independent variable on the dependent variable (except for the proportional representation dummy and postcommunist dummy that take values 0 or 1). Constant not shown. Full results can be found in Table A4 in the appendix.

While this represents a test at the macro level, there is also evidence at the micro level that is based on survey data and corroborates our argument that labour market institutions have a crucial impact on far right votes. A study by Arzheimer (2009), for example, supports our claim that unemployment benefits have both a mediating and direct effect on far right support. He investigates cross-national variation in western Europe before eastern enlargement, combining system-level variables with individual sociodemographic and attitudinal data in the period between 1980 and 2002 and including in the analysis cases where the far right performed poorly. His results show a statistically significant effect of unemployment benefits in reducing far right party support, although he suggests that this effect is not particularly strong overall (ibid: 271). His findings concerning the interaction between unemployment benefit systems and unemployment rates are also consistent with our argument. Specifically, he finds that 'a positive effect [of unemployment rates] becomes visible but only in contexts when either levels of immigration or benefits are very low' and that 'at high levels of immigration, unemployment benefits reduce the impact of unemployment' (ibid: 272). 
Figure 8 Plotting how the interaction between unemployment and EPL correlates with far right party support in the last three EP elections

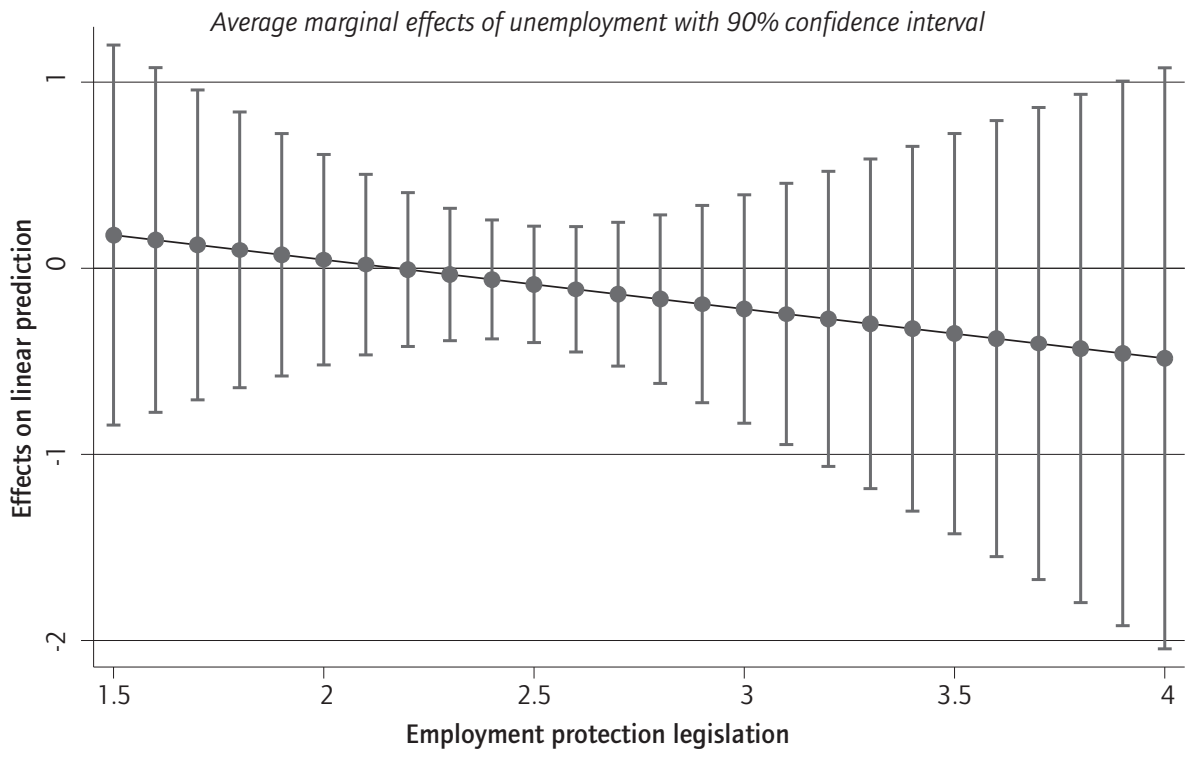

Note: Full results can be found in Table A4 in the appendix.

Figure 9 Plotting how the interaction between unemployment and unemployment benefits correlates with far right party support in the last three EP elections

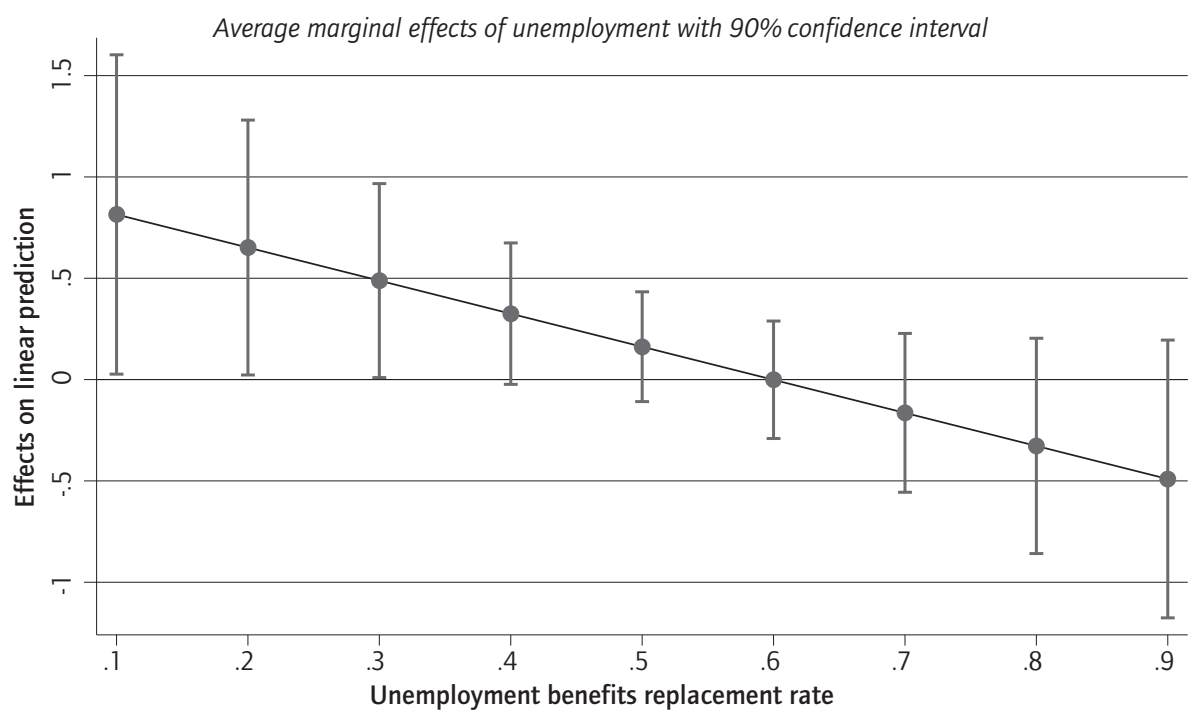

Note: Full results can be found in Table A4 in the appendix. 
Figure 10 Plotting how the interaction between the change in unemployment and unemployment benefits correlates with far right party support in the last three EP elections

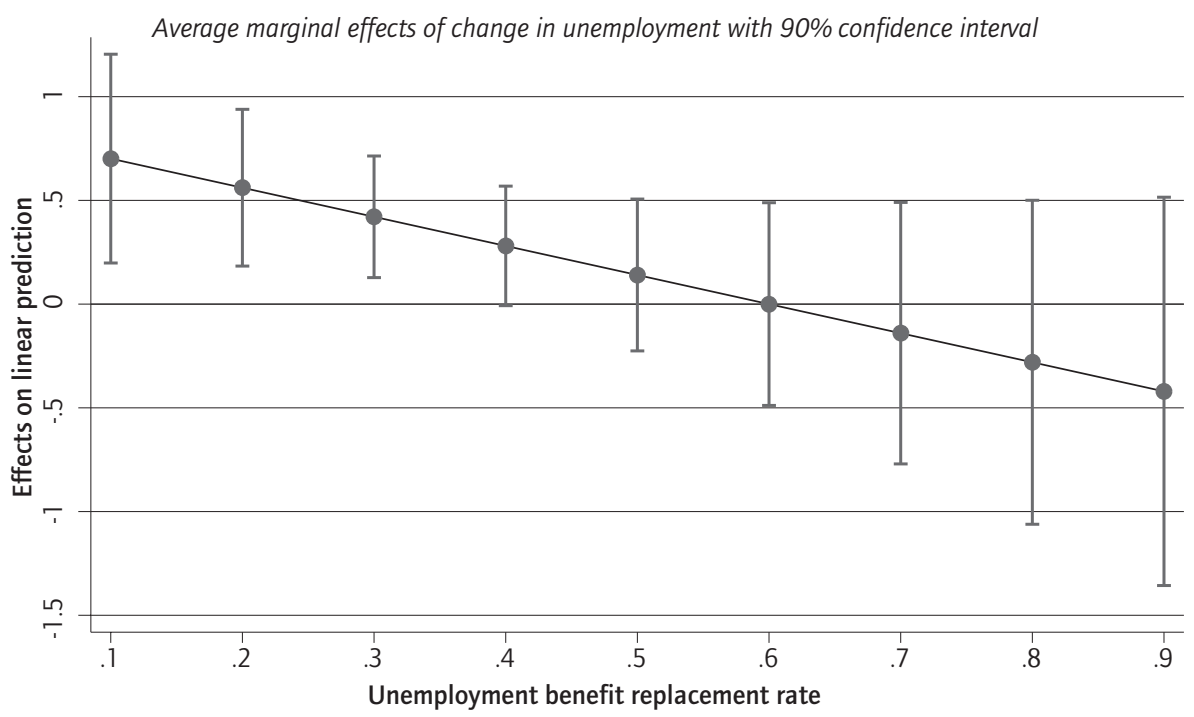

Note that more than $10 \%$ of observations are 0.4 or less. Full results can be found in Table A4 in the appendix.

Figure 11 Plotting how the interaction between unemployment, unemployment benefits and EPL correlates with far right party support in the last three EP elections

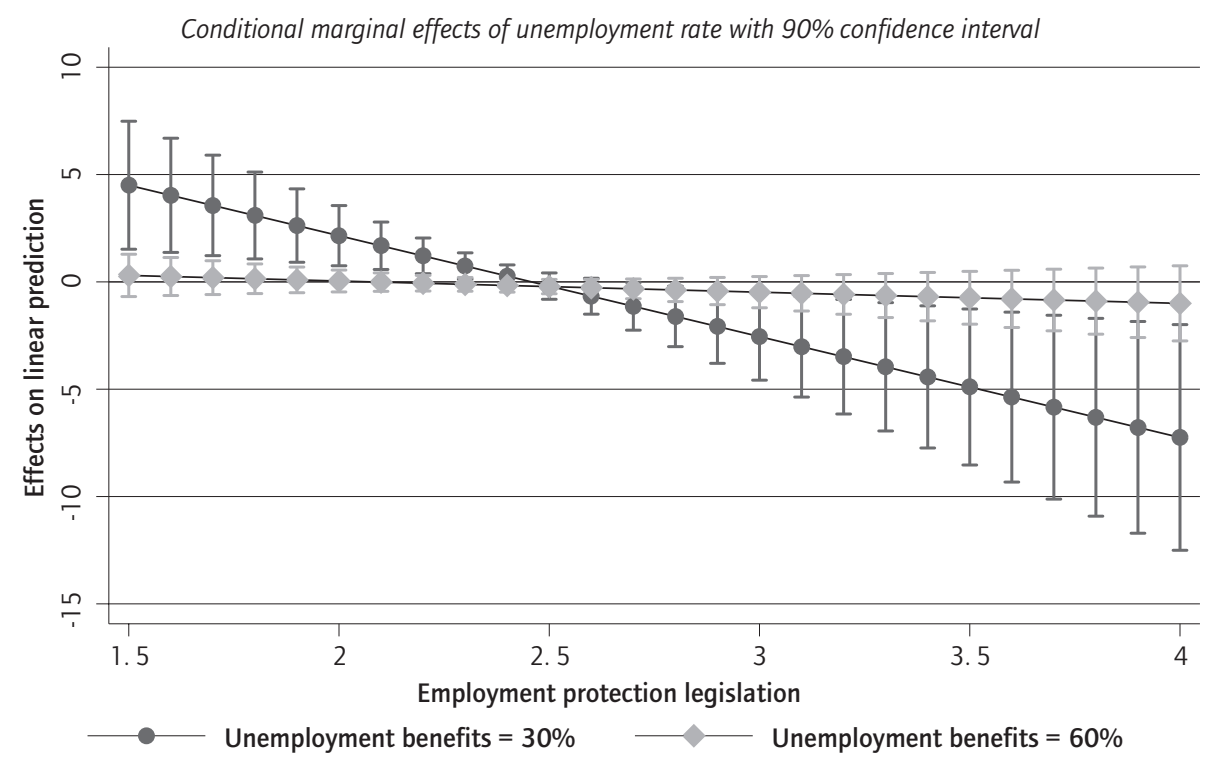

Note that roughly $20 \%$ of observations have an EPL index range from 1.5 to 2 - see histogram in the appendix. Note: Full results can be found in Table A4 in the appendix. 


\section{Conclusion}

Does economic distress facilitate right-wing extremism and, if so, how may we understand the different patterns of far right party support across Europe? While many theories focus on the effect of the economy itself, there are conflicting expectations and contradictory findings concerning this approach. Indeed, the cross-national variation in unemployment rates and far right support in recent EP elections is not prima facie consistent with a direct impact of unemployment on the far right. When they do coincide, the causal mechanism linking economic malaise and far right party support is unclear.

To address this issue, this paper has reconceptualised the effect of unemployment on far right support. Our theoretical framework centres on the mediating effect of labour market institutions, focusing in particular on EPL and unemployment benefits. In this way, we specify the causal mechanism that links economic distress to far right party support at times of crisis: where labour market institutions offer greater protection from the risks and costs of unemployment, the far right is less likely to fare well electorally. Where, on the other hand, these institutions are less generous, the risks and costs of unemployment are greater and the far right is more likely to increase its support.

We tested our argument on the last three EP elections and found that unemployment and GDP growth per se are not statistically significant. Unemployment benefits have both a direct association with far right support and an indirect association through limiting the effect of unemployment: where unemployment benefits are generous, unemployment has no association with far right support, but where they are not, unemployment correlates with higher support for the far right. EPL only has an indirect association conditional on unemployment benefits: where unemployment benefits are low, EPL mediates the impact of unemployment; but where unemployment benefits are generous, there is no mediating impact of EPL.

The aim of this paper was to identify certain broad associations, which can then be examined in greater detail in further research. We have relied on statistical methods to explore these associations. Our findings are consistent with the patterns observed in certain country case studies, such as the UK, where the far right has experienced increased support as a result of low EPL and unemployment benefits, or Portugal, where both labour market institutions have remained protective and the far right has not attracted any significant support. At the same time, these methods are limited in their ability to explain all single country cases. This is because individual case study dynamics may 
reinforce or break patterns identified in our analysis; in Spain, for instance, the history of authoritarianism is an important political dynamic that hinders the success of far right parties (see for example Alonso and Kaltwasser 2015).

Despite these limitations, our results have wider implications. They suggest that the rise of the far right is not merely the result of exogenous forces that are outside of policy makers' control. On the contrary, it is more likely the outcome of labour market policy choices. In a number of European countries, governments of both the left and right have reduced entitlements to unemployment benefits and have deregulated job security regulations. As a result, the unemployed have seen their standard of living deteriorate, while a growing segment of the labour force now works on temporary contracts and workers on permanent contracts feel increasingly insecure. The most affected economies have responded to the financial crisis by pursuing policies of austerity (Theodoropoulou and Watt 2011), further exacerbating economic uncertainty. The irony is that it is precisely these policies, targeted at solving Europe's economic predicament, that have intensified political instability in many European countries. If we are right, the adoption of these policies increases the risks and costs of unemployment, which, in turn, makes the rise of the far right more likely. Social democratic parties and the union movement should continue to oppose austerity not only because of its adverse economic effects, but also because of its dangerous political consequences in times of crisis. 


\section{References}

Alonso S. and Kaltwasser S.R. (2015) Spain: no country for the populist radical right?, South European Society and Politics, 20 (1), 21-45.

Klaus Armingeon, Romana Careja, Laura Knöpfel, David Weisstanner, Sarah Engler, Panajotis Potolidis, Marlène Gerber. 2013. Comparative Political Data Set III 1990-2011. Bern: Institute of Political Science, University of Berne.

Arzheimer K. (2009) Contextual factors and the extreme right vote in Western Europe, 1980-2002, American Journal of Political Science, 53 (2), 259-275.

Baccaro L. and Rei D. (2007) Institutional determinants of unemployment in OECD countries: does the deregulatory view hold water?, International Organization, 61 (3), 527-569.

Bassanini A. and Duval R. (2006) Employment patterns in OECD countries: reassessing the role of policies and institutions, OECD Social, Employment and Migration Working Papers No. 35, Paris, OECD Publishing.

Bassanini A. and Duval R. (2009) Unemployment, institutions, and reform complementarities: re-assessing the aggregate evidence for OECD countries, Oxford Review of Economic Policy, 25 (1), 40-59.

Betz H.G. (1994) Radical right-wing populism in Western Europe, New York, St. Martin's Press.

Böckerman P. (2004) Perception of job instability in Europe, Social Indicators Research, 67 (3), 283-314.

Brambor T., Clark W.R. and Golder M. (2006) Understanding interaction models: improving empirical analyses, Political Analysis, 14 (1), 63-82.

Chung H. and Carr E. (2014) Employment insecurity and life satisfaction: the moderating influence of labour market policies across Europe, Journal of European Social Policy, 24 (4), 383-399.

Chung $\mathrm{H}$. and van Oorschot W. (2011) Institutions versus market forces: explaining the employment insecurity of European individuals during (the beginning of) the financial crisis, Journal of European Social Policy, 21 (4), 287-301.

Clark A. and Postel-Vinay F. (2005) Job security and job protection, CEP Discussion Paper No. 678. http://cep.lse.ac.uk/pubs/download/dp0678.pdf

Cochrane C. and Nevitte N. (2014) Scapegoating: unemployment, far-right parties and anti-immigrant sentiment, Comparative European Politics, 12 (1), 1-32.

De Koster W., Achterberg P. and van der Waal J. (2012) The new right and the welfare state: the electoral relevance of welfare chauvinism and welfare populism in the Netherlands, International Political Science Review, 34(1), 3-20.

De Witte H. (1999) Job insecurity and psychological well-being: review of the literature and exploration of some unresolved issues, European Journal of Work and Organizational Psychology, 8 (2), 155-177.

DPI2012 (2012) Database of Political Institutions: Changes and Variable Definitions. Philip Keefer, Development Research Group, The World Bank.

Eatwell R. (2000) The rebirth of the 'extreme right' in Western Europe?, Parliamentary Affairs, 53 (3), 407-425.

Ellwood S. (1995) The extreme right in Spain, in Cheles L., Ferguson R. and Vaughan M. (eds.) The far right in Western and Eastern Europe, London, Longman.

Emmenegger P. (2012) Job security regulations in Western democracies: a fuzzy-set analysis, European Journal of Political Research, 50 (3), 336-364. 
Emmenegger P., Häusermann S., Palier B. and Seeleib-Kaiser M. (eds.) (2012) The age of dualization: the changing face of inequality in deindustrializing societies, Oxford, Oxford University Press.

Ennser L. (2012) The homogeneity of West European party families: the radical right in comparative perspective, Party Politics, 18 (2), 151-171.

Esping-Andersen G. (1990) The three worlds of welfare capitalism, Princeton, Princeton University Press.

Falzon M.A. and Micallef M. (2012) Rights, roots and routes: local and transnational contexts of extreme right movements in contemporary Malta, in Mammone A., Godin E. and Jenkins B. (eds.) Mapping the extreme right in contemporary Europe: from local to transnational, London, Routledge.

Garrett G. (1998) Partisan politics in the global economy, New York, Cambridge University Press.

Gerlach K. and Stephan G. (1996) A paper on unhappiness and unemployment in Germany, Economics Letters, 52 (3), 325-330.

Golder M. (2003) Explaining variation in the success of extreme right parties in Western Europe, Comparative Political Studies, 36 (4), 432-466.

Hainsworth P. (2008) The extreme right in Western Europe, London, Routledge.

Halikiopoulou D., Nanou K. and Vasilopoulou S. (2012) The paradox of nationalism: the common denominator of radical right and radical left euroscepticism, European Journal of Political Research, 51 (4), 504-539.

Halikiopoulou D. and Vlandas T. (2015) Risks, costs and labour markets: explaining cross-national patterns of far right party success in European Parliament elections, JCMS: Journal of Common Market Studies, 54 (3), 636-655.

Harrison S. and Bruter M. (2011) Mapping extreme right ideology: an empirical geography of the European extreme right, Basingstoke, Palgrave Macmillan.

Hartley J. et al. (1991) Job insecurity: coping with jobs at risk, London, Sage.

Hix S. and Marsh M. (2007) Punishment or protest? Understanding European Parliament elections, The Journal of Politics, 69 (2), 495-510.

Immerzeel T., Lubbers M. and Coffé H. (2015) Competing with the radical right: distances between the European radical right and other parties on typical radical right issues, Party Politics. doi: 10.1177/1354068814567975

Ivarsflaten E. (2008) What unites right-wing populists in Western Europe? Re- examining grievance mobilization models in seven successful cases, Comparative Political Studies, 41 (1), 3-23.

Jahoda M. (1988) Economic recession and mental health: some conceptual issues, Journal of Social Issues, 44 (4), 13-23.

Kaufmann E. (2014) 'It's the demography, stupid': ethnic change and opposition to immigration, The Political Quarterly, 85 (3), 267-276.

Katsourides Y. (2013) Determinants of extreme right reappearance in Cyprus: the National Popular Front (ELAM), Golden Dawn's Sister Party, South European Society and Politics, 18 (4), 567-589.

Kitschelt H. and McGann A. (1995) The radical right in Western Europe: a comparative analysis, Ann Arbor, University of Michigan Press.

Kitschelt H. (2007) Growth and persistence of the radical right in postindustrial democracies: advances and challenges in comparative research, West European Politics, 30 (5), 1176-1206.

Kriesi H. (2014) The populist challenge, West European Politics, 37 (2), 361-378. 
Kriesi H. et al. (2006) Globalization and the transformation of the national political space: six European countries compared, European Journal of Political Research, 45 (6), 921-956

Lipset S.M. (1960) Political man: the social bases of politics, New York, Doubleday. Lubbers M., Gijsberts M. and Scheepers P. (2002) Extreme right-wing voting in Western Europe, European Journal of Political Research, 41 (3), 345-378.

Lubbers M. and Scheepers P. (2002) French Front National voting: a micro and macro perspective, Ethnic and Racial Studies, 25 (1), 120-149.

Lucassen G. and Lubbers M. (2012) Who fears what? Explaining far-right-wing preference in Europe by distinguishing perceived cultural and economic ethnic threats, Comparative Political Studies, 45 (5), 547-574.

Mares M. (2012) Right-wing extremism in the Czech Republic, International Policy Analysis, Berlin, Friedrich Ebert Foundation.

Marx P. and Picot G. (2013) The party preferences of atypical workers in Germany, Journal of European Social Policy, 23 (2), 164-178.

Marx P. (2014) Labour market risks and political preferences: the case of temporary employment, European Journal of Political Research, 53 (1), 136-159.

Mau S., Mewes J. and Schöneck N.M. (2012) What determines subjective socio-economic insecurity? Context and class in comparative perspective, Socio-Economic Review, $10(4), 655-682$.

Mudde C. (2007) Populist radical right parties in Europe, Cambridge, Cambridge University Press.

Mudde C. (2010) The populist radical right: a pathological normalcy, West European Politics, 33 (6), 1167-1186.

Minkenberg M. and Perrineau P. (2007) The radical right in the European elections 2004, International Political Science Review, 28 (1), 29-55.

Mughan A. and Lacy D. (2002) Economic performance, job insecurity and electoral choice, British Journal of Political Science, 32 (3), 513-533.

OECD (1994) The OECD jobs study: facts, analysis, strategies, Paris, Organisation for Economic Co-operation and Development.

OECD (2004) Employment protection regulation and labour market performance, in OECD Employment Outlook 2004, Paris, Organisation for Economic Co-operation and Development, 61-125.

Pankowski R. (2010) The populist radical right in Poland: the patriots, London, Routledge.

Pankowsk R. and Kormak M. (2013) Radical nationalism in Poland: from theory to practice, in Melzer R. and Serafin S. (eds.) Right-wing extremism in Europe: country analyses, counter-strategies and labor-market oriented exit strategies, Berlin, Friedrich Ebert Foundation, 157-168.

Plümper T., Troeger V.E. and Manow P. (2005) Panel data analysis in comparative politics: linking method to theory, European Journal of Political Research, 44 (2), 327-354.

Pytlas B. (2013) Radical-right narratives in Slovakia and Hungary: historical legacies, mythic overlaying and contemporary politics, Patterns of Prejudice, 47 (2), 162-183.

Rueda D. (2005) Insider-outsider politics in industrialized democracies: the challenge to social democratic parties, American Political Science Review, 99 (1), 61-74.

Rueda D. (2006) Social democracy and active labour market policies: insiders, outsiders, and the politics of employment promotion, British Journal of Political Science, 36 (3), $385-406$ 
Rueda D. (2007) Social democracy inside out: partisanship and labor market policy in industrialized democracies, Oxford, Oxford University Press.

Rueda D. (2014) Dualization, crisis and the welfare state, Socio-Economic Review, 12 (2), 381-407.

Rydgren J. (2007) The sociology of the radical right, Annual Review of Sociology, 33, 241-262.

Rydgren J. (ed.) (2013) Class politics and the radical right, London, Routledge.

Reif K. and Schmitt H. (1980) Nine second-order national elections: a conceptual framework for the analysis of European election results, European Journal of Political Research, 8 (1), 3-44.

Scheve K. and Slaughter M.J. (2004) Economic insecurity and the globalization of production, American Journal of Political Science, 48 (4), 662-674.

Sniderman P.M. and Hagendoorn L. (2007) When ways of life collide: multiculturalism and its discontents in the Netherlands, Princeton, Princeton University Press.

Swank D. and Betz H.G. (2003) Globalization, the welfare state and right-wing populism in Western Europe, Socio-Economic Review, 1 (2), 215-245.

Theodoropoulou S. and Watt A. (2011) Withdrawal symptoms: an assessment of the austerity packages in Europe, Working Paper 2011.02, Brussels, ETUI.

Van Vliet O. and Caminada K. (2012) Unemployment replacement rates dataset among 34 welfare states, 1971-2009: an update, extension and modification of Scruggs' Welfare State Entitlements Data Set, NEUJOBS Special Report No. 2, Leiden University.

van der Eijk C. and Franklin M.N. (eds.) (1996) Choosing Europe? The European electorate and national politics in the face of union, Ann Arbor, University of Michigan Press.

Vasilopoulou S. (2011) European integration and the radical right: three patterns of opposition, Government and Opposition, 46 (2), 223-244.

Vasilopoulou S. and Halikiopoulou D. (2015) The Golden Dawn's 'nationalist solution': explaining the rise of the far right in Greece, New York, Palgrave Pivot.

Vlandas T. (2013) The politics of temporary work deregulation in Europe: solving the French puzzle, Politics and Society, 41 (3), 425-460.

Wimmer A. (1997) Explaining xenophobia and racism: a critical review of current research approaches, Ethnic and Racial Studies, 20 (1), 17-41. 


\section{List of abbreviations}

EP - European Parliament

EPL - Employment protection legislation

UBS - Unemployment benefit system 


\section{Appendix}

\section{Appendix 1 Sources for coding of far right wing parties}

\begin{tabular}{|c|c|c|}
\hline Country & Far right wing party & Sources \\
\hline Austria & Austrian Freedom Party (FPÖ) & Immerzeel et al. (2015) \\
\hline Austria & Alliance for the Future of Austria (BZÖ) & Immerzeel et al. (2015) \\
\hline Belgium & Flemish Interest (VB) & Immerzeel et al. (2015) \\
\hline Bulgaria & National Union Attack (ATAKA) & Immerzeel et al. (2015) \\
\hline Croatia & Croatian Party of Rights (HSP) & Immerzeel et al. (2015) \\
\hline Cyprus & National Popular Front (ELAM) & Katsourides (2013) \\
\hline Czech Republic & Workers' Party of Social Justice (DSSS) & Mareš (2012) \\
\hline Denmark & Danish People's Party (DF) & Immerzeel et al. (2015) \\
\hline Estonia & Estonian Independence Party (EIP) & Immerzeel et al. (2015) \\
\hline Finland & True Finns (PS) & Immerzeel et al. (2015) \\
\hline France & National Front (FN) & Immerzeel et al. (2015) \\
\hline Germany & National Democratic Party of Germany (NPD) & Immerzeel et al. (2015) \\
\hline Germany & The Republicans (REP) & Immerzeel et al. (2015) \\
\hline Greece & Golden Dawn (GD) & Vasilopoulou and Halikiopoulou (2015) \\
\hline Greece & Popular Orthodox Rally (LAOS) & Immerzeel et al. (2015) \\
\hline Greece & Independent Greeks (ANEL) & Vasilopoulou and Halikiopoulou (2015) \\
\hline Hungary & Movement for a better Hungary (Jobbik) & Immerzeel et al. (2015) \\
\hline Ireland & N/A & \\
\hline Italy (LN) & Northern League (LN) & Immerzeel et al. (2015) \\
\hline Latvia & National Alliance (NA) & Vasilopoulou (2011) \\
\hline Lithuania & Order and Justice party (TT) & Rydgren (2013) \\
\hline Luxemburg & National Movement (NB) & Lubbers et al. (2002) \\
\hline Malta & Imperium Europa (IE) & Minkenberg and Perrineau (2007); Falzon and Micallef (2012) \\
\hline Netherlands & Party for Freedom (PVV) & Immerzeel et al. (2015) \\
\hline Netherlands & List Pim Fortuyn (LPF) & Harrison and Bruter (2011) \\
\hline Poland & Law and Justice Party (Pis) & $\begin{array}{l}\text { Pankowski (2010); Harrison and Bruter (2011); Pankowski and } \\
\text { Kormak (2013) }\end{array}$ \\
\hline Poland & Congress of the New Right (KPN) & Harrison and Bruter (2011) \\
\hline Poland & League of Polish Families (LPR) & Harrison and Bruter (2011); Immerzeel et al. (2015) \\
\hline Portugal & National Renovator Party (PNR) & Immerzeel et al. (2015) \\
\hline Romania & Greater Romanian Party (PRM) & Immerzeel et al. (2015) \\
\hline Slovakia & Slovak National Party (SNS) & Immerzeel et al. (2015) \\
\hline Slovakia & People's Party-Our Slovakia (L'SNS) & Pytlas (2013) \\
\hline Slovenia & Slovenian National Party (SNS) & Immerzeel et al. (2015) \\
\hline Spain & National Democracy (DN) & Ellwood (1995) \\
\hline Sweden & Sweden Democrats (SD) & Immerzeel et al. (2015) \\
\hline UK & British National Party (BNP) & Immerzeel et al. (2015) \\
\hline UK & United Kingdom Independence Party (UKIP) & Immerzeel et al. (2015) \\
\hline
\end{tabular}


Table A2 Descriptive statistics for variables used

\begin{tabular}{|c|c|c|c|c|c|}
\hline Variable & $\begin{array}{c}\text { (1) } \\
\text { Observations }\end{array}$ & $\begin{array}{l}(2) \\
\text { Mean }\end{array}$ & $\begin{array}{c}\text { (3) } \\
\text { Standard } \\
\text { deviation }\end{array}$ & $\begin{array}{c}\text { (4) } \\
\text { Minimum } \\
\text { value }\end{array}$ & $\begin{array}{c}\text { (5) } \\
\text { Maximum } \\
\text { value }\end{array}$ \\
\hline Far right votes & 80 & 7.305 & 8.812 & 0 & 38.93 \\
\hline Unemployment benefit replacement rate & 79 & 0.583 & 0.137 & 0.260 & 0.900 \\
\hline Unemployment rate & 84 & 8.737 & 4.525 & 3.100 & 27.50 \\
\hline Parliamentary fragmentation & 81 & 4.784 & 1.706 & 2.024 & 10.07 \\
\hline Proportional representation dummy & 81 & 0.926 & 0.264 & 0 & 1 \\
\hline EPL index & 61 & 2.607 & 0.448 & 1.558 & 4.095 \\
\hline Real GDP growth & 83 & 1.517 & 2.710 & -5.400 & 8.600 \\
\hline Post-communist dummy & 84 & 0.357 & 0.482 & 0 & 1 \\
\hline Trade as $\%$ of GDP & 84 & 113.8 & 65.86 & 0 & 371.4 \\
\hline Share of industrial employment & 83 & 27.10 & 6.027 & 12.40 & 40.20 \\
\hline $\begin{array}{l}\text { Immigration as \% of recipient country's } \\
\text { population }\end{array}$ & 84 & 0.008 & 0.007 & 0 & 0.038 \\
\hline Euroscepticism & 69 & 53.21 & 13.49822 & 27 & 85 \\
\hline EP election turnout & 80 & 45.66 & 19.05 & 13.05 & 91.22 \\
\hline Change in unemployment & 84 & -0.25 & 3.96 & -12 & 17.9 \\
\hline
\end{tabular}




\section{Table A3 Definitions and sources for variables for European elections sample}

\begin{tabular}{|c|c|c|}
\hline Variable & Description & Sources \\
\hline $\begin{array}{l}\% \text { vote for far right } \\
\text { parties }\end{array}$ & $\begin{array}{l}\% \text { vote for far right parties. For our classification see Appendix } \\
\text { 2. Years used for each country: 2004, } 2009 \text { and } 2014 \text {. }\end{array}$ & $\begin{array}{l}\text { For far right results: EU Election Database } \\
\text { http://eed.nsd.uib.no/webview/index.jsp?study=h } \\
\text { ttp://129.177.90.166:80/obj/fStudy/ATEP2004 } \\
\text { _Display\&node=0\&mode=cube\&v=2\&cube=http:/ } \\
\text { /129.177.90.166:80/obj/fCube/ATEP2004_Disp } \\
\text { lay_C1\&top=yes } \\
\text { and http://www.europarl.europa.eu/elections } \\
\text { 2014-results/en/election-results-2014.html }\end{array}$ \\
\hline Unemployment rate & $\begin{array}{l}\text { Unemployment rates represent unemployed persons as a } \\
\text { percentage of the labour force. Years used for each country: } \\
2003,2008 \text { and } 2013 \text {. }\end{array}$ & Eurostat \\
\hline Real GDP & $\begin{array}{l}\text { Real GDP growth rate - volume. Percentage change on previous } \\
\text { year. Years used for each country: 2003, } 2008 \text { and } 2013 \text {. }\end{array}$ & Eurostat \\
\hline $\begin{array}{l}\text { Post-communist } \\
\text { dummy }\end{array}$ & $\begin{array}{l}\text { Equals } 1 \text { for } 12 \text { countries that joined the EU in } 2004 \text { and } 2007 \\
\text { enlargements (excluding Cyprus and Malta) }\end{array}$ & Author's calculation \\
\hline $\begin{array}{l}\text { Unemployment } \\
\text { benefits }\end{array}$ & $\begin{array}{l}\text { Net unemployment replacement rate for an average worker, one } \\
\text { earner couple with two children. The dataset scales the } \\
\text { replacement rate between } 0 \text { and } 1 \text { (i.e. } 0.75 \text { means that that } \\
75 \% \text { of the income prior to unemployment is replaced by } \\
\text { unemployment benefits). Years used for each country: } 2003 \text {, } \\
2008 \text { and } 2011 \text {. }\end{array}$ & Van Vliet and Caminada (2012) \\
\hline $\begin{array}{l}\text { Electoral } \\
\text { frationalisation }\end{array}$ & $\begin{array}{l}\text { Index of electoral fractionalization of the party system } \\
\text { according to the formula [F] proposed by Rae (1968). Years } \\
\text { used for each country: 2003, } 2008 \text { and } 2011 .\end{array}$ & Armingeon et al. (2013) \\
\hline $\begin{array}{l}\text { Proportional } \\
\text { representation dummy }\end{array}$ & $\begin{array}{l}\text { Proportional Representation? ( } 1 \text { if yes, } 0 \text { if no): "1" if candidates } \\
\text { are elected based on the percent of votes received by their party } \\
\text { and/or if our sources specifically call the system "proportional } \\
\text { representation". "0" otherwise. Years used for each country: } \\
2003,2008 \text { and } 2011 \text {. }\end{array}$ & DPI2012 (2012) \\
\hline $\begin{array}{l}\text { Total trade } \\
\text { (\% of GDP) }\end{array}$ & $\begin{array}{l}\text { Sum of Export and Import of Goods and Services, \% of GDP. } \\
\text { Years used for each country: 2003, } 2008 \text { and } 2013 .\end{array}$ & Eurostat \\
\hline Industry & Industry employment as \% of Total Employment & European Commission \\
\hline $\begin{array}{l}\text { Employment } \\
\text { Protection Index }\end{array}$ & $\begin{array}{l}\text { The OECD indicators of employment protection legislation } \\
\text { measure the procedures and costs involved in dismissing } \\
\text { individuals or groups of workers. Strictness of employment } \\
\text { protection - individual and collective dismissals (regular } \\
\text { contracts). Years used for each country: 2003, } 2008 \text { and } 2013 .\end{array}$ & $\begin{array}{l}\text { OECD database accessible at: } \\
\text { http://www.oecd.org/els/emp/oecdindicatorsofe } \\
\text { mploymentprotection.htm }\end{array}$ \\
\hline Total Immigration & $\begin{array}{l}\text { In percentages. Years used for each country: 2003, } 2008 \text { and } \\
2012 .\end{array}$ & Eurostat \\
\hline $\begin{array}{l}\text { Effective number of } \\
\text { parties }\end{array}$ & $\begin{array}{l}\text { Effective number of parties on the votes level according to the } \\
\text { formula [N2] pro-posed by Laakso and Taagepera (1979). Years } \\
\text { used for each country: 2003, } 2008 \text { and } 2011 .\end{array}$ & Armingeon et al. (2013) \\
\hline EP turnout & $\begin{array}{l}\text { Voter turnout in the EP Elections as a percentage of the total of } \\
\text { eligible voters }\end{array}$ & $\begin{array}{l}\text { The data for EP turnout are accessed at: } \\
\text { http://www.nsd.uib.no/european_election_databa } \\
\text { se/election_types/ep_elections/ and } \\
\text { http://www.europarl.europa.eu/elections2014- } \\
\text { results/en/turnout.html }\end{array}$ \\
\hline Support for the EU & $\begin{array}{l}\text { Percentage of people who answered 'a good thing' to the } \\
\text { question: 'Generally speaking, do you think that (OUR } \\
\text { COUNTRY)'s membership of the EU is...?' }\end{array}$ & $\begin{array}{l}\text { This data was extracted from the following three } \\
\text { Eurobarometer reports: } 79.5,69,59 \text {. }\end{array}$ \\
\hline
\end{tabular}




\section{Table A4 Full results for figures 4 to 11}

\begin{tabular}{|c|c|c|c|c|c|c|c|c|c|}
\hline Column & (1) & (2) & (3) & (4) & (5) & (6) & (7) & (8) & (9) \\
\hline Results for figure & 4 & 4 & 4 & 5 & 5 & 5 & 6 & 6 & 6 \\
\hline Unemployment rate & $\begin{array}{r}0.05 \\
(0.067)\end{array}$ & $\begin{array}{r}-0.01 \\
(0.087)\end{array}$ & $\begin{array}{r}-0.03 \\
(0.091)\end{array}$ & & & & $\begin{array}{r}-0.03 \\
(0.091)\end{array}$ & $\begin{array}{r}-0.03 \\
(0.092)\end{array}$ & $\begin{array}{r}0.05 \\
(0.105)\end{array}$ \\
\hline Real GDP growth & $\begin{array}{r}-0.04 \\
(0.040)\end{array}$ & $\begin{array}{r}-0.04 \\
(0.040)\end{array}$ & $\begin{array}{r}-0.07 \\
(0.065)\end{array}$ & $\begin{array}{r}-0.04 \\
(0.042)\end{array}$ & $\begin{array}{r}-0.04 \\
(0.038)\end{array}$ & $\begin{array}{r}-0.08 \\
(0.066)\end{array}$ & $\begin{array}{r}-0.07 \\
(0.065)\end{array}$ & $\begin{array}{r}-0.07 \\
(0.067)\end{array}$ & $\begin{array}{r}-0.03 \\
(0.083)\end{array}$ \\
\hline Electoral fragmentation & $\begin{array}{r}0.26 t \\
(0.133)\end{array}$ & $\begin{array}{r}0.22 t \\
(0.129)\end{array}$ & $\begin{array}{r}0.22 \\
(0.142)\end{array}$ & $\begin{array}{c}0.27^{*} \\
(0.131)\end{array}$ & $\begin{array}{r}0.23 t \\
(0.128)\end{array}$ & $\begin{array}{r}0.22 \\
(0.140)\end{array}$ & $\begin{array}{r}0.22 \\
(0.142)\end{array}$ & $\begin{array}{r}0.22 \\
(0.142)\end{array}$ & $\begin{array}{r}0.27 t \\
(0.159)\end{array}$ \\
\hline Immigration & $\begin{array}{r}0.06 \\
(0.100)\end{array}$ & $\begin{array}{r}0.02 \\
(0.114)\end{array}$ & $\begin{array}{r}0.09 \\
(0.122)\end{array}$ & $\begin{array}{r}0.05 \\
(0.098)\end{array}$ & $\begin{array}{r}0.03 \\
(0.108)\end{array}$ & $\begin{array}{r}0.10 \\
(0.122)\end{array}$ & $\begin{array}{r}0.09 \\
(0.122)\end{array}$ & $\begin{array}{r}0.09 \\
(0.117)\end{array}$ & $\begin{array}{r}0.17 \\
(0.141)\end{array}$ \\
\hline Trade openness & & $\begin{array}{r}-0.14 \\
(0.150)\end{array}$ & $\begin{array}{r}-0.14 \\
(0.183)\end{array}$ & & $\begin{array}{r}-0.14 \\
(0.153)\end{array}$ & $\begin{array}{r}-0.14 \\
(0.179)\end{array}$ & $\begin{array}{r}-0.14 \\
(0.183)\end{array}$ & $\begin{array}{r}-0.14 \\
(0.190)\end{array}$ & $\begin{array}{r}-0.25 \\
(0.188)\end{array}$ \\
\hline Industrialisation & & $\begin{array}{r}-0.20 \\
(0.135)\end{array}$ & $\begin{array}{r}-0.23 \\
(0.168)\end{array}$ & & $\begin{array}{r}-0.20 \\
(0.124)\end{array}$ & $\begin{array}{r}-0.21 \\
(0.142)\end{array}$ & $\begin{array}{r}-0.23 \\
(0.168)\end{array}$ & $\begin{array}{r}-0.22 \\
(0.169)\end{array}$ & $\begin{array}{r}-0.22 \\
(0.183)\end{array}$ \\
\hline Post-communist dummy & & & $\begin{array}{r}0.74 \\
(0.688)\end{array}$ & & & $\begin{array}{r}0.72 \\
(0.642)\end{array}$ & $\begin{array}{r}0.74 \\
(0.688)\end{array}$ & $\begin{array}{r}0.79 \\
(0.709)\end{array}$ & $\begin{array}{r}1.02 \\
(0.771)\end{array}$ \\
\hline Proportional representation & & & $\begin{array}{l}-1.34^{* *} \\
(0.508)\end{array}$ & & & $\begin{array}{l}-1.36^{\star \star} \\
(0.508)\end{array}$ & $\begin{array}{l}-1.34^{\star *} \\
(0.508)\end{array}$ & $\begin{array}{l}-1.38^{\star *} \\
(0.513)\end{array}$ & $\begin{array}{l}-1.52^{*} \\
(0.606)\end{array}$ \\
\hline Change unemployment rate & & & & $\begin{array}{r}0.03 \\
(0.061)\end{array}$ & $\begin{array}{r}-0.01 \\
(0.071)\end{array}$ & $\begin{array}{r}-0.02 \\
(0.073)\end{array}$ & & & \\
\hline Voter turnout EP elections & & & & & & & & $\begin{array}{r}0.04 \\
(0.144)\end{array}$ & $\begin{array}{r}0.06 \\
(0.149)\end{array}$ \\
\hline Euroscepticism & & & & & & & & & $\begin{array}{r}0.13 \\
(0.133)\end{array}$ \\
\hline Constant & $\begin{array}{r}0.01 \\
(0.186)\end{array}$ & $\begin{array}{r}0.02 \\
(0.177)\end{array}$ & $\begin{array}{r}1.05^{*} \\
(0.535)\end{array}$ & $\begin{array}{r}0.01 \\
(0.185)\end{array}$ & $\begin{array}{r}0.02 \\
(0.178)\end{array}$ & $\begin{array}{c}1.08^{*} \\
(0.525)\end{array}$ & $\begin{array}{r}1.05^{*} \\
(0.535)\end{array}$ & $\begin{array}{r}1.07 t \\
(0.546)\end{array}$ & $\begin{array}{r}1.18 t \\
(0.634)\end{array}$ \\
\hline Observations & 78 & 78 & 75 & 78 & 78 & 75 & 75 & 75 & 67 \\
\hline Number of countries & 27 & 27 & 26 & 27 & 27 & 26 & 26 & 26 & 26 \\
\hline R-squared within model & 0.15 & 0.10 & 0.12 & 0.14 & 0.11 & 0.13 & 0.12 & 0.13 & 0.29 \\
\hline R-squared overall model & 0.00 & 0.06 & 0.21 & 0.00 & 0.06 & 0.20 & 0.21 & 0.20 & 0.19 \\
\hline R-squared between model & 0.00 & 0.06 & 0.23 & 0.00 & 0.06 & 0.23 & 0.23 & 0.23 & 0.16 \\
\hline
\end{tabular}

Note: robust standard errors clustered by country in parentheses; ${ }^{* *} p<0.001,{ }^{*}{ }^{*} p<0.01,{ }^{*} p<0.05$, t $p<0.1$ 
Table A4 Full results for figures 4 to 11 (continued)

\begin{tabular}{|c|c|c|c|}
\hline Column & (10) & (11) & (12) \\
\hline Results for figure & 7 & 7 & 7 \\
\hline Unemployment rate & $\begin{array}{r}0.04 \\
(0.077)\end{array}$ & $\begin{array}{r}-0.04 \\
(0.074)\end{array}$ & $\begin{array}{r}-0.04 \\
(0.098)\end{array}$ \\
\hline Real GDP growth & $\begin{array}{r}-0.14 \\
(0.098)\end{array}$ & $\begin{array}{r}-0.13 \\
(0.095)\end{array}$ & $\begin{array}{l}-0.21^{*} \\
(0.095)\end{array}$ \\
\hline Electoral fragmentation & $\begin{array}{r}0.28 t \\
(0.165)\end{array}$ & $\begin{array}{r}0.29 \\
(0.178)\end{array}$ & $\begin{array}{r}0.32 t \\
(0.182)\end{array}$ \\
\hline Immigration & $\begin{array}{r}0.25^{*} \\
(0.106)\end{array}$ & $\begin{array}{c}0.28^{*} \\
(0.120)\end{array}$ & $\begin{array}{r}0.29 t \\
(0.165)\end{array}$ \\
\hline Trade openness & & $\begin{array}{r}-0.24 \\
(0.208)\end{array}$ & $\begin{array}{r}-0.14 \\
(0.340)\end{array}$ \\
\hline Industrialisation & & $\begin{array}{l}-0.32 * \\
(0.144)\end{array}$ & $\begin{array}{r}-0.25 \\
(0.239)\end{array}$ \\
\hline Post-communist dummy & & & $\begin{array}{r}0.26 \\
(0.974)\end{array}$ \\
\hline Proportional representation & & & $\begin{array}{l}-1.14^{* *} \\
(0.350)\end{array}$ \\
\hline EPL & $\begin{array}{r}-0.08 \\
(0.163)\end{array}$ & $\begin{array}{r}-0.03 \\
(0.172)\end{array}$ & $\begin{array}{r}0.05 \\
(0.143)\end{array}$ \\
\hline Unemployment benefits & $\begin{array}{l}-0.64^{* *} \\
(0.213)\end{array}$ & $\begin{array}{l}-0.69 * * \\
(0.240)\end{array}$ & $\begin{array}{l}-0.71^{\text {** }} \\
(0.226)\end{array}$ \\
\hline Constant & $\begin{array}{r}0.05 \\
(0.201)\end{array}$ & $\begin{array}{r}0.03 \\
(0.185)\end{array}$ & $\begin{array}{r}1.02 * \\
(0.428)\end{array}$ \\
\hline Observations & 61 & 61 & 59 \\
\hline Number of id & 22 & 22 & 21 \\
\hline R-squared within model & 0.31 & 0.30 & 0.32 \\
\hline R-squared overall model & 0.19 & 0.32 & 0.41 \\
\hline R-squared between model & 0.14 & 0.30 & 0.39 \\
\hline
\end{tabular}

Note: robust standard errors clustered by country in parentheses; ${ }^{* *} p<0.001,{ }^{*} p<0.01,{ }^{*} p<0.05, t p<0.1$. Note that the EPL index has lower country coverage and therefore the number of countries in the analysis drops when including the EPL index. 
Table A4 Full results for figures 4 to 11 (continued)

\begin{tabular}{|c|c|c|c|c|}
\hline Column & (13) & (14) & (15) & (16) \\
\hline Results for figure & 8 & 9 & 10 & 11 \\
\hline Real GDP growth & $\begin{array}{r}-0.59 \\
(0.384)\end{array}$ & $\begin{array}{r}-0.09 \\
(0.285)\end{array}$ & $\begin{array}{r}-0.05 \\
(0.325)\end{array}$ & $\begin{array}{r}-0.15 \\
(0.292)\end{array}$ \\
\hline Electoral fragmentation & $\begin{array}{r}0.36 \\
(0.228)\end{array}$ & $\begin{array}{c}0.39 * \\
(0.152)\end{array}$ & $\begin{array}{c}0.38^{*} \\
(0.159)\end{array}$ & $\begin{array}{r}0.44^{*} \\
(0.200)\end{array}$ \\
\hline Immigration & $\begin{array}{r}357.87 \\
(269.395)\end{array}$ & $\begin{array}{r}227.90 \\
(187.753)\end{array}$ & $\begin{array}{r}218.01 \\
(185.006)\end{array}$ & $\begin{array}{r}305.06 \\
(245.380)\end{array}$ \\
\hline Post-communist dummy & $\begin{array}{r}7.40 \\
(9.649)\end{array}$ & $\begin{array}{r}-0.82 \\
(5.589)\end{array}$ & $\begin{array}{r}0.37 \\
(5.582)\end{array}$ & $\begin{array}{r}6.45 \\
(7.878)\end{array}$ \\
\hline Proportional representation dummy & $\begin{array}{l}-9.22^{* *} \\
(2.808)\end{array}$ & $\begin{array}{r}-9.75^{* * *} \\
(2.944)\end{array}$ & $\begin{array}{r}-9.47^{\star * *} \\
(2.865)\end{array}$ & $\begin{array}{l}-7.58^{* *} \\
(2.921)\end{array}$ \\
\hline Trade openness & $\begin{array}{r}-0.05 \\
(0.040)\end{array}$ & $\begin{array}{r}-0.02 \\
(0.020)\end{array}$ & $\begin{array}{r}-0.02 \\
(0.021)\end{array}$ & $\begin{array}{r}-0.05 \\
(0.036)\end{array}$ \\
\hline Industrialisation & $\begin{array}{r}-0.42 \\
(0.386)\end{array}$ & $\begin{array}{r}-0.26 \\
(0.236)\end{array}$ & $\begin{array}{r}-0.32 \\
(0.220)\end{array}$ & $\begin{array}{r}-0.53 t \\
(0.316)\end{array}$ \\
\hline EP voter turnout & $\begin{array}{r}0.02 \\
(0.114)\end{array}$ & $\begin{array}{r}-0.04 \\
(0.077)\end{array}$ & $\begin{array}{r}-0.04 \\
(0.075)\end{array}$ & $\begin{array}{r}.09 \\
(0.131)\end{array}$ \\
\hline Euroscepticism & $\begin{array}{r}0.05 \\
(0.109)\end{array}$ & $\begin{array}{r}0.04 \\
(0.082)\end{array}$ & $\begin{array}{r}0.07 \\
(0.085)\end{array}$ & $\begin{array}{r}0.05 \\
(0.103)\end{array}$ \\
\hline Unemployment rate & $\begin{array}{r}0.75 \\
(1.596)\end{array}$ & $\begin{array}{r}0.98 t \\
(0.578)\end{array}$ & & $\begin{array}{r}22.02^{* *} \\
(8.410)\end{array}$ \\
\hline Change in unemployment rate & & & $\begin{array}{c}0.84^{*} \\
(0.393)\end{array}$ & \\
\hline EPL & $\begin{array}{r}2.26 \\
(4.720)\end{array}$ & & & $\begin{array}{r}49.33^{*} \\
(23.790)\end{array}$ \\
\hline Unemployment benefits & $\begin{array}{c}-36.22^{*} \\
(14.672)\end{array}$ & $\begin{array}{c}-29.69 * \\
(13.004)\end{array}$ & $\begin{array}{c}-41.79 * * * \\
(12.678)\end{array}$ & $\begin{array}{l}148.93 * \\
(71.769)\end{array}$ \\
\hline Unemployment*EPL & $\begin{array}{r}-0.35 \\
(0.648)\end{array}$ & & & $\begin{array}{c}-8.88^{*} \\
(3.496)\end{array}$ \\
\hline Unemployment* unemployment benefits & & $\begin{array}{r}-1.63 \\
(1.044)\end{array}$ & & $\begin{array}{l}-34.90^{* *} \\
(12.370)\end{array}$ \\
\hline Change in unemployment rate*unemployment benefits & & & $\begin{array}{r}-1.40 \\
(0.997)\end{array}$ & \\
\hline$E P L * u n e m p l o y m e n t ~ b e n e f i t s$ & & & & $\begin{array}{c}-76.00^{*} \\
(32.971)\end{array}$ \\
\hline Unemployment* EPL* unemployment benefits & & & & $\begin{array}{l}13.93^{* *} \\
(5.139)\end{array}$ \\
\hline Constant & $\begin{array}{r}16.01 \\
(18.854)\end{array}$ & $\begin{array}{r}11.86 \\
(12.330)\end{array}$ & $\begin{array}{r}19.69 \\
(13.315)\end{array}$ & $\begin{array}{r}-102.76 t \\
(57.060)\end{array}$ \\
\hline Observations & 55 & 65 & 65 & 55 \\
\hline Number of id & 21 & 25 & 25 & 21 \\
\hline R-squared within model & 0.34 & 0.34 & 0.37 & 0.36 \\
\hline R-squared overall model & 0.44 & 0.39 & 0.37 & 0.51 \\
\hline R-squared between model & 0.42 & 0.41 & 0.37 & 0.54 \\
\hline
\end{tabular}

Note: robust standard errors clustered by country in parentheses; ${ }^{* *} p<0.001,{ }^{*} p<0.01,{ }^{*} p<0.05, t p<0.1$. Note that the EPL index has lower country coverage and therefore the number of countries in the analysis drops when including the EPL index. 
Table A5 Robustness to change in sample

\begin{tabular}{|c|c|c|c|c|}
\hline $\begin{array}{l}\text { Column } \\
\text { Change }\end{array}$ & $\begin{array}{c}\text { (1) } \\
\text { No change }\end{array}$ & $\begin{array}{l}\text { (2) } \\
\text { Excluding } \\
\text { Poland }\end{array}$ & $\begin{array}{l}\text { (3) } \\
\text { Excluding } \\
\text { Spain }\end{array}$ & $\begin{array}{l}\text { (4) } \\
\text { Excluding countries with } \\
0 \text { support for far right }\end{array}$ \\
\hline Unemployment rate & $\begin{array}{r}-0.06 \\
(0.097)\end{array}$ & $\begin{array}{r}-0.12 \\
(0.114)\end{array}$ & $\begin{array}{r}-0.00 \\
(0.106)\end{array}$ & $\begin{array}{r}-0.02 \\
(0.136)\end{array}$ \\
\hline Real GDP growth & $\begin{array}{r}-0.19 \\
(0.126)\end{array}$ & $\begin{array}{r}-0.20 \\
(0.125)\end{array}$ & $\begin{array}{r}-0.18 \\
(0.133)\end{array}$ & $\begin{array}{r}-0.04 \\
(0.157)\end{array}$ \\
\hline Electoral fractionalisation & $\begin{array}{r}0.33 \\
(0.212)\end{array}$ & $\begin{array}{r}0.24 \\
(0.214)\end{array}$ & $\begin{array}{r}0.31 \\
(0.232)\end{array}$ & $\begin{array}{r}0.55^{\star} \\
(0.261)\end{array}$ \\
\hline Immigration as \% & $\begin{array}{r}0.29 \\
(0.232)\end{array}$ & $\begin{array}{r}0.08 \\
(0.219)\end{array}$ & $\begin{array}{r}0.28 \\
(0.240)\end{array}$ & $\begin{array}{r}0.40 t \\
(0.239)\end{array}$ \\
\hline EPL & $\begin{array}{r}-0.01 \\
(0.193)\end{array}$ & $\begin{array}{r}-0.06 \\
(0.174)\end{array}$ & $\begin{array}{r}-0.02 \\
(0.203)\end{array}$ & $\begin{array}{r}0.10 \\
(0.214)\end{array}$ \\
\hline Unemployment benefits & $\begin{array}{l}-0.56^{*} \\
(0.222)\end{array}$ & $\begin{array}{l}-0.31^{*} \\
(0.142)\end{array}$ & $\begin{array}{l}-0.53^{*} \\
(0.232)\end{array}$ & $\begin{array}{l}-0.50^{*} \\
(0.236)\end{array}$ \\
\hline Total trade & $\begin{array}{r}-0.39 \\
(0.305)\end{array}$ & $\begin{array}{r}-0.25 \\
(0.246)\end{array}$ & $\begin{array}{r}-0.40 \\
(0.312)\end{array}$ & $\begin{array}{r}-0.61 \\
(0.535)\end{array}$ \\
\hline Industrialisation & $\begin{array}{r}-0.30 \\
(0.258)\end{array}$ & $\begin{array}{r}-0.22 \\
(0.208)\end{array}$ & $\begin{array}{r}-0.30 \\
(0.261)\end{array}$ & $\begin{array}{l}-0.64^{\star *} \\
(0.215)\end{array}$ \\
\hline Post-communist & $\begin{array}{r}0.86 \\
(1.088)\end{array}$ & $\begin{array}{r}0.47 \\
(0.812)\end{array}$ & $\begin{array}{r}0.84 \\
(1.108)\end{array}$ & $\begin{array}{r}1.95 t \\
(1.002)\end{array}$ \\
\hline Proportional representation & $\begin{array}{l}-1.04^{\star *} \\
(0.330)\end{array}$ & $\begin{array}{l}-1.05^{\star *} \\
(0.374)\end{array}$ & $\begin{array}{l}-1.02^{* *} \\
(0.342)\end{array}$ & $\begin{array}{r}-0.66 \\
(0.531)\end{array}$ \\
\hline Voter turnout in EP elections & $\begin{array}{r}0.02 \\
(0.235)\end{array}$ & $\begin{array}{r}0.14 \\
(0.195)\end{array}$ & $\begin{array}{r}0.02 \\
(0.245)\end{array}$ & $\begin{array}{r}-0.02 \\
(0.261)\end{array}$ \\
\hline Support for Europe & $\begin{array}{r}0.09 \\
(0.174)\end{array}$ & $\begin{array}{r}-0.02 \\
(0.184)\end{array}$ & $\begin{array}{r}0.11 \\
(0.192)\end{array}$ & $\begin{array}{r}-0.10 \\
(0.222)\end{array}$ \\
\hline Constant & $\begin{array}{r}0.83^{*} \\
(0.370)\end{array}$ & $\begin{array}{r}0.84^{*} \\
(0.379)\end{array}$ & $\begin{array}{r}0.84^{*} \\
(0.385)\end{array}$ & $\begin{array}{r}0.41 \\
(0.609)\end{array}$ \\
\hline Observations & 55 & 53 & 52 & 45 \\
\hline Number of id & 21 & 20 & 20 & 18 \\
\hline R-squared within model & 0.35 & 0.26 & 0.36 & 0.41 \\
\hline R-squared overall model & 0.44 & 0.44 & 0.41 & 0.55 \\
\hline R-squared between model & 0.41 & 0.46 & 0.39 & 0.59 \\
\hline
\end{tabular}

Note: robust standard errors clustered by country in parentheses; ${ }^{* *} p<0.001,{ }^{* *} p<0.01,{ }^{*} p<0.05, t p<0.1$ 
Figure A1 Histogram of employment protection legislation

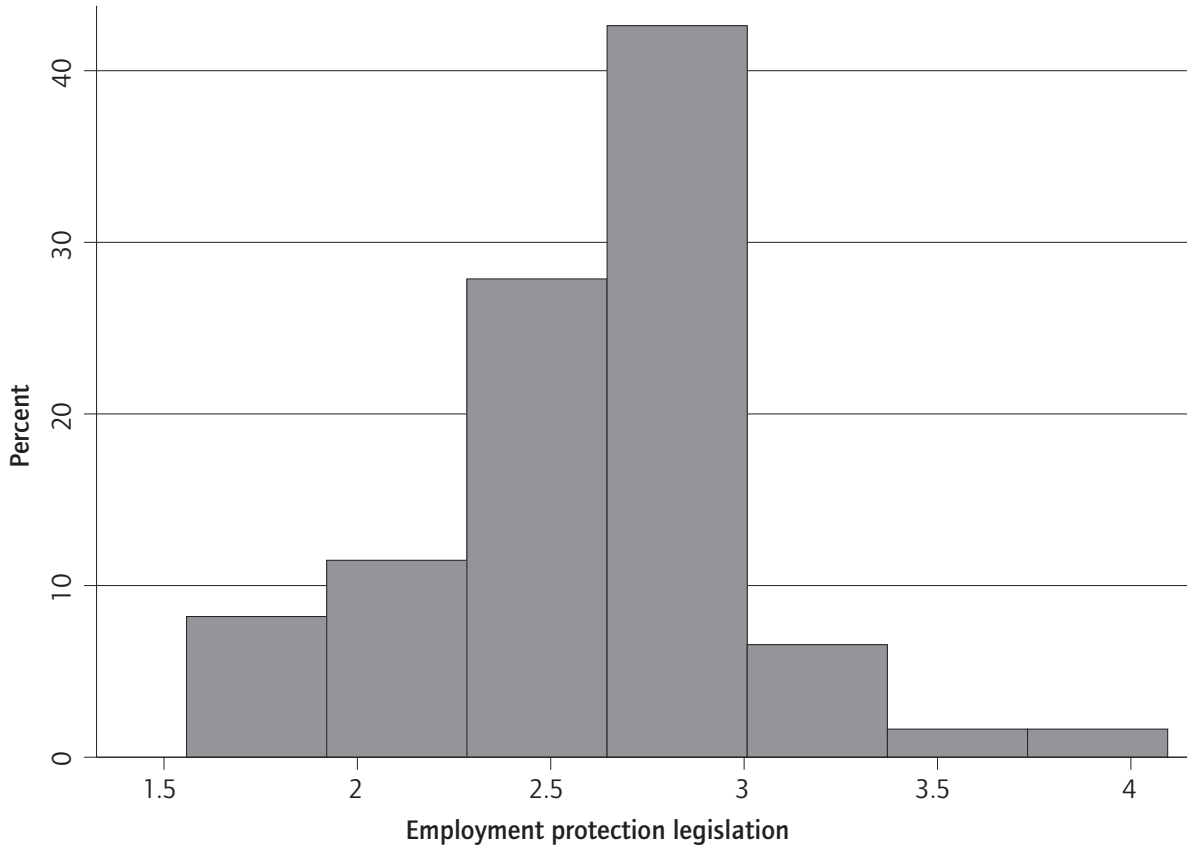

Figure A2 Histogram of unemployment benefits

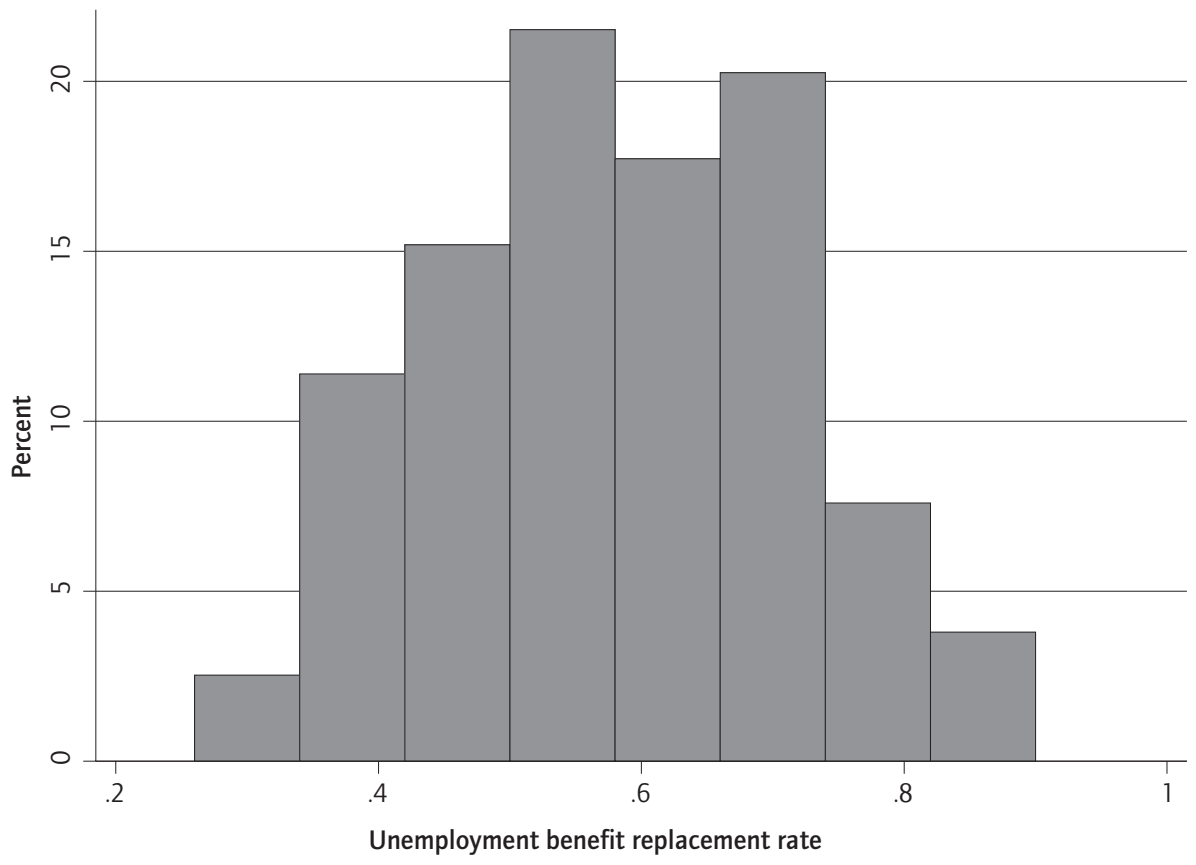

Note: as noted earlier, this data covers three data points - 2003, 2008 and 2009 - because 2009 is the latest year for which data is available. 